Portland State University

PDXScholar

Dissertations and Theses

Dissertations and Theses

1975

\title{
An evaluative study of Yellow Brick Road
}

Cherry Hartman

Portland State University

Nan Narboe

Portland State University

Follow this and additional works at: https://pdxscholar.library.pdx.edu/open_access_etds

Part of the Social Work Commons

Let us know how access to this document benefits you.

\section{Recommended Citation}

Hartman, Cherry and Narboe, Nan, "An evaluative study of Yellow Brick Road" (1975). Dissertations and Theses. Paper 2158.

https://doi.org/10.15760/etd.2156

This Thesis is brought to you for free and open access. It has been accepted for inclusion in Dissertations and Theses by an authorized administrator of PDXScholar. Please contact us if we can make this document more accessible: pdxscholar@pdx.edu. 
AN EVALUATIVE STUDY

OF YELLOW BRICK ROAD

by

CWERRY IAATTMAN

MAN NARBOE

A practicum subnteted in partial fulfiliment

of the requitrements for the degree of

MSTERS OF SOCTAL WORK

Portland state University

1975

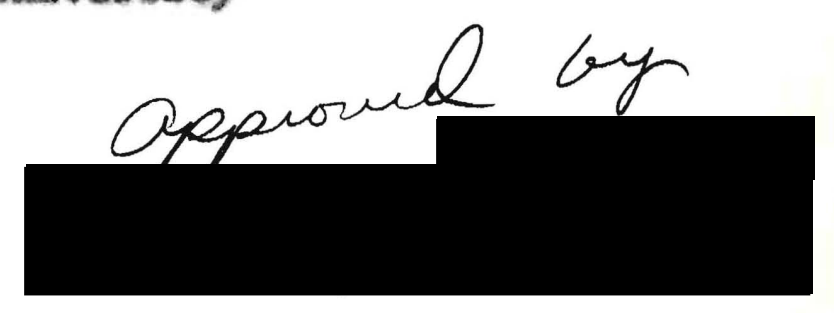


FOREWOND

This study was conpleted as partiel fulflilment of the regutrement for the Masters of Soctal Work degree from the School of Soelal Work at Rortland State Universtey. The study was done by Nan Narboe and Cherry Hartman wh much asszatance fron Nancy Roroloff, faculty advisor.

The study was ortglnally concelved and infelated because of our oun desire to evaluate a program which we had created, shaped and directed and because of our destre to "reward" progran partielpants and supporters wh feedback as to "how we "re dolng,"

"In house" research way be seen as unusual or unorthodox. Wo felt there were many advantages to researching our own progran, greatest of these was intereat. As Project Director (Cherry Martman) and Trainer (Nan Narboe) we had great investment in the progran and in the research. Data collection and analysis was not viewed as a chore but rather as an excelting adventure thich could have rtch payoefs, Our fandliarty with the prograra and Its particlpants Lacilitated the study design and data collection. of particular importance, was our position to actually ut111ze the data, We atrongly belleve that research has 4 ts greatest value in practical application. This study has had much influence upon the on-golng development of Yellow BrLelc Road. Of 
couree, because $2 t$ was our own progran we were studylng, It was of great value to have the outstde perspectlve provlded by Nancy Rorolofe to avold our blind spots and Inside "jargon."

Both Nan and I are comnltted to the use of paraprofesglonals in the area of counseling and we have oxperienced great satisfaction in completing a study which makes a posttive statement about paraprofesstonals as counselors. 
PAGE

FOREWORD .......................

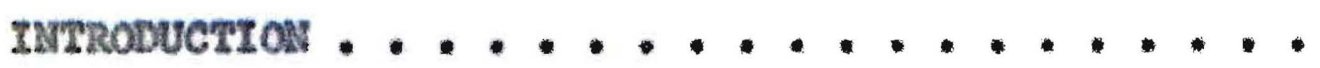

PROGRAM RATYORAL, IISTOKX AND DESICN

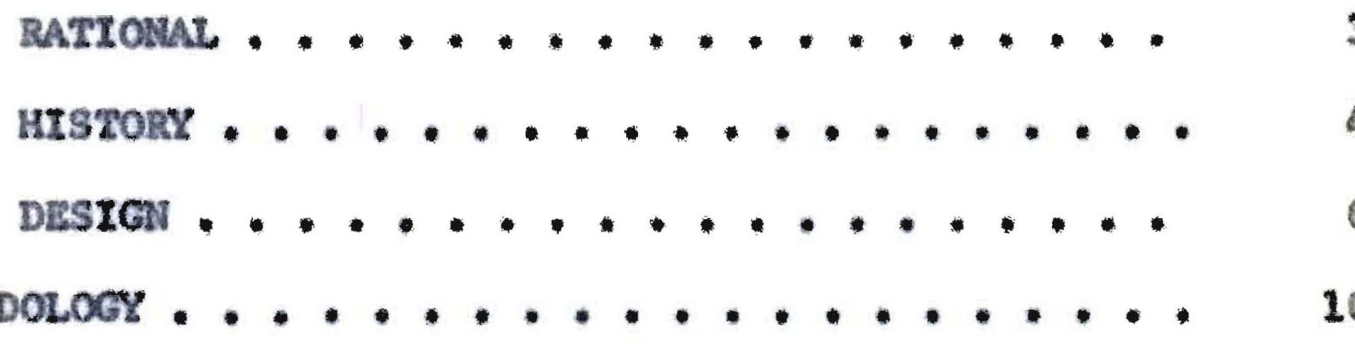

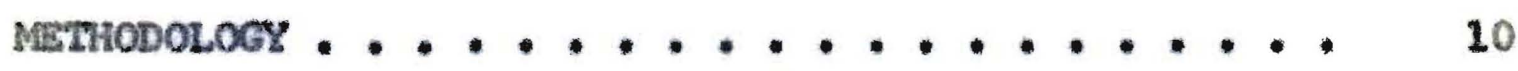

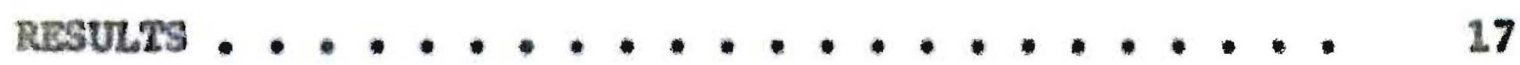

INTERPREXATION AND CONCLUSIONS

INTERPRETATION OF RESULTS . . . . . . . . 23

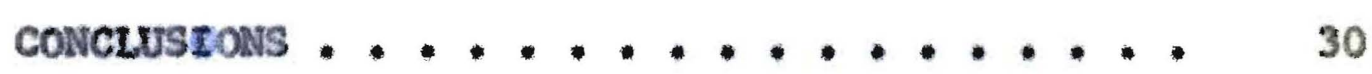

uTrLIzATION .......................... 31

EPILOGUE ............................... 34

APPEIDICES

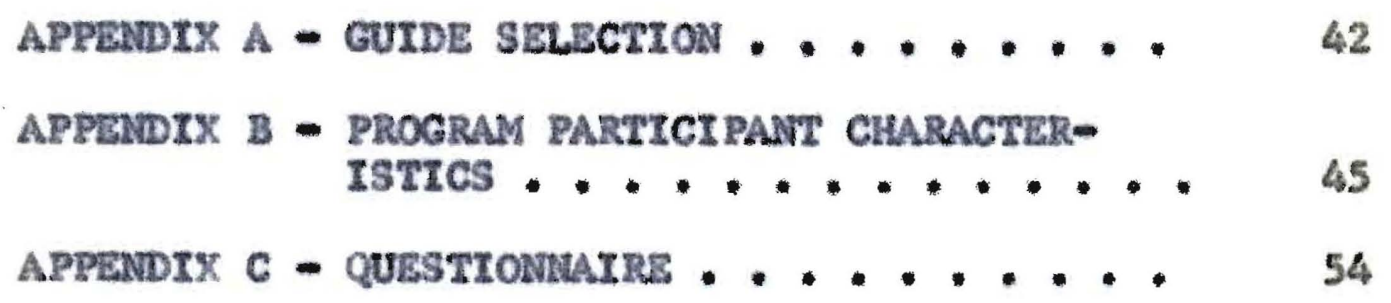


TABLE

PAGE

I Dete Retrieval 1973..............,

II Date Retrteval 1974..............

III BLock-byeblocic Compar2son, 1973. . ....

IV BLoclk-by-31ock CorgarLson, 1974. . . *. .

V Intra-BLock Conststency. ............... 


\section{INTIODUCTION}

This is a study of Yellow Brtek Road" a paraprofessional volunteer tralning and group counseling progras. The study was designed to help determine whether or not the program was meeting its ow goals whlch are stated ast 1) to offer clients an expertence wheh not only helps then to effect ehanges in their 1ives, but to maintaln those changes through heal thy time-restructuringtw within a supportive environment; 2) to denonstrate that volunteers who are undergolng Intensive training can provide guallty counseling and other services; 3) to create a coununity environnent supportive of healthy change.

Tovard evaluating these broadly stated goals, this study will spectflcally look at these factors: 1) ellent satisfaction, 2) internal program conslatency, 3) activity group valldity, that 1s, whether or not activity groups contribute to the change process,

Yellow Brick Road is a untque progran whleh 1 a deslgned to use volunteer paraprofesstonal in highly sophlaticated leadershsp roles facilitating change and growth of program

-The program was naned from the Whzard of On and relates to selfediscovery.

twithe concept of timemrestructuring is from firlc Berne the creator of Transactional Analysis, It is recognized by Transactional Analysis thersplsts as part of the change 
clients. To meastre acceptance of these volunteer as group leaders by paying clients by looking at the factors mentioned above was an Important goal of the study.

Since volunteers at different stages of tralning and experlence were leading groups, internal program consl, stency was of interest. Were all volunteer group leaders viewed by thelr clients equally or were sone seen more favorably than others? If group leaderg were vilewed less favorably did thelz elients still feel they had had a valuable growth experLence in Yellow BrLek Road?

Another aspect of the Yellow Briclc road desLgn which Is unique is that it combines tine-restructuring activity groups wth counseling groups. A client is olmultaneously Involved In both groups, one followng the other, on the same night. It was hypothestaed that these actuvity groups would be as Liportant ad junct to a cllent's counseling expertence. Dtd clients thinik so? 


\section{PROGRAM RATTONAL, HISTORY AND DESTGN}

\section{Rational}

Yellow Brick Road was designed, Inttiated and sponsored by Lutheran Fanaly Service of Oregon, a sall, private soctal service agency based in Portland, Oregon. Its fundIng and support base is fron the Lutheran Church, the Untted Way and client fees, The agency functions wth three primary sections, 1) Crisis section, which offers a vartety of counseling and training programs, 2) Growth section, which Is devoted to strengthening family IIfe and developing conw muntey resources which are fandly oriented, 3) Structural Change section, whlch 18 sesrching for ways to deal with hunan problens wthin public systens. A spinmoff agency located In Portland's poverty area (AlbLna Fandiy and CommunIty Services) is the wost vistble result of this section.

Yellow Bfick Ioad is one program of Lutheran Fandly Service's Crisis sectlon. Yellow Brtck Ioad was created out of a bellef that helphing people to give up destructive behavlor patterns is not enough. It is also necessary and destrable to asst people in developlng new, postetve iffe styles. Lutheran Fantly Service had viewed Itself as successful in meeting the needs of ellents in crises situation; famly problens, potential sulcides, marttal conflicts, etc., 
however, wany cllants were expressing the need for something more-a direction in whtch to nove after resolving the intthal problen.

Also, many cllents expressed interest in helplng others. Tradielonally, ageneles such as Lutheran Family Service have mace 11tele use of paraprofesstonal volunteers. At the same the, agency expansion and growth had been 1intted by the relattvely small number of tralned professionals on staff. Adding professionsl staff seemed a short term solucton, as an additlonal staff person was avallable, client intake increased and soon the demand for services was agaln greater thin staff could meet. Therefore, it seened cruclal to recognize this growing resource of potentlal volunteers, respond to it and develop $1 t$.

\section{Hatory}

In the fall of 1972, Intervievs for potential volunteers were begun. Twenty were to be selected and over one hundred vere intervieved. The great response vass explained by the Eact that volunteers were, in exchange for thelr teime, energy, and comaltment, to be glven tralning in Transactional Analyals and Gestalt Therapy (treatnent methods eraployed by Lutheran Fanily Service cotanseling staff).

The response allowed for selectivity in choosing the 
volunteers. The selections were made by the following criterta: 1) fantliartty with Transactional Analysis, 2) awareness, 3) completed successfiul therapy or equivalent, 4) tratnabLitty, 5) special skil1., (See Appendix $A$, Criteria for Tralnees and Origtnal Gulde Selection.)

After the program was inftiated, new volunteers were accepted Intermittentiy. The crtterta was changed to add the stipulation that a potential volunteer anust first go through the progran as a client and be evaluated by those volunteers who had worked wh or observed him/her. (See Appendix A, Gulde Applicant's Evaluation.)

The origlnal twenty volunteers carne from widely varyIng backgrounda, Occupations represented were English professor, program director, housewlfe, nurse, soctal woric student, secretary, speech theraplst, chlld speclallst, high school teacher, yoga instructor, artist. Several were unerployed. Echcational degrees were not Included in selection criterla, thus educational backgrounds ranged from not having completed high sehool to the doctorate level. Economic levels were diverse. Annual incomes ranged from \$2500 to $\$ 20,000$. Eleven of the volunteers were women, nine ware men. Age range was frota 23 to 55 years. (See Appendix B, Program Participant (haracteristics.)

Because the use of volunteers and paraprofesstonals 
as counselors was still experimental, it was decided to avold the use of efther term and refer to the persons as Gutces. Later, advanced Gutdes were used to tratn others and they became lnowa as PLots.

The Guldes were gtven some inttial training expertences and then began woricing with twenty progran clients, called Travelers, in January, 1973.

Travelexs were referred to the program by Lutheran Fandly Service staff (wany had prevlously been agency cllents) and by PACT (Portland Action Conanttees Together) which serves a Low-incone area in Southeast Portland. Travelers pald $\$ 28$ for 28 progran hours. The relatively Low fee was weant to allow persons who are normally prohlbited by the high cost of therapy to partictpate in a growth progras. Some Travelers were gtven scholarships by Portland Action Comdttaes Together. (See Appendix B, Progran Partlcipant Characteristics for description of Travelers in the first ehree sesstons of Yellow Brick Rosd, 1973.)

Destm

The progran operated on Sunday nights from 6:00 p.m. to $10: 00 \mathrm{p}$, w. (This was deternined to be the time slot most readily avallable to the nost people and 1t allowed for partictpation by people who are regularly employed.) The foux 
hours was divided into two, one and three quarter hour sesslons wheh a hall hour break between the two.

Each elfent was Involved in a baste coumseling group called Change group, ether flrst or mecond sesclon, The altemate time perlod was apent in a time-restructuring activity group." A Change group and an activity group together made up a Route. For esumple, a ellent in Route 1 would be in a Change group followed by a Yoga activity group. A ellent in Route 2 would be in a conamity action activity group followed by a Change group.

FTCURE 1: SAMRLE PROGRAM SCHEDULE

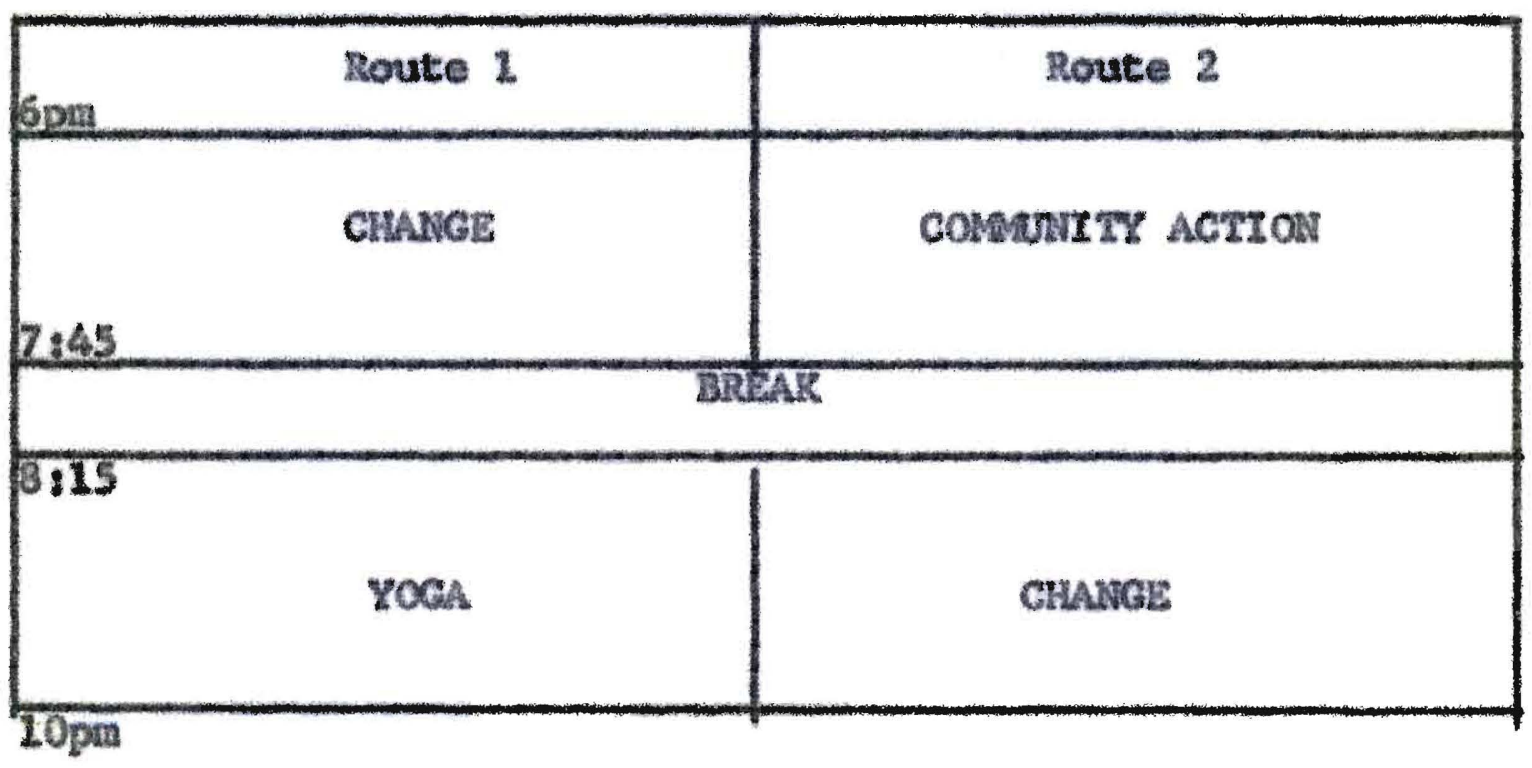

The activity groups were designed to help Travelexs

*Activity groups offered throughout 1973 and 1974 were Art, Community Action, Psychodrana, Dance, Body Awareness, Yoga, Transactional Analysis for Rin, Relaxation and Sense Awareness. 
Increase awareness of themselves and how they interact wth other people, to provide a safe, atructured setting to experiment with new behavlor, and to help Travolers look at how they structure tine and increase awareness of optsons for tima strueturing.

Bach group was co-led by two Guldes. A Gutde led only one group and was in a tralning group curling the altwzrate time pertod. Tratntng focused on Transactional Analysis and Gestalt Therapy theory and methodology, wh emphasts on debrlefing tapes of the ellent groups. AddLtonal, optlonal. tralning experlences were offered twice a month. These were session there Guldes could have personal counseling experiences, as personal growth was seen as a ma for component of the training program.

New Guldes were glven an Intenstve, stx week tralning progran and then becane observers in cluent groups. They gave feedback to Guide group leaders and leamed by watching. Guides did not begin to lead ellent groups until they felt ready and then they were palred wh more experienced leader:

Rald stafe of the Yellow Brlck Road progran conststed of a Progran Director who put in 15 to 20 hours per weel in the progran and a Trainer who put in 10 to 15 hours per week. Both persons were counselors at Lutheran Fantly Service. 
The program was divided into six-week segments. The segnents were called Blocles. There were Elve Blociss within each program year. 
Beffore the first group of Yellow Brtek Road clients had complated the progran, a guestlonnalre was destgned (See Appendix $C_{*}$ ) which was to be adndnistered to clients at the end of the final sesston. The questionnatre was designed to:

A. Relate to the spectiftc faetors of:

1. Client astisection

2. Internal progran const stency

3. Activity group validity

B. Relate to a stmilax guestlonnalre which has been used wth Lutheran Fanily Service counseling groups so that it would be possible to do a comparison study. (This has not been completed.)

Since the questlonnalres were admintstered on the last atght of each Block, It was felt that the "high apLrtes" of the Guldes and Pravelers may have affected the responses, therefore, a follow-up questionnatre (Ldentelcal to the OrIgLnal) was adnlns stered to a 50 percent randon sample of the population of Blocik 4, 1974, three months Later.

The folloutng questiona were designed to glve Information about elient sats fection:

Question 1. Wy expectations of Yellow Brlck Road were net: (favorably, unfavorably).

Question 2. What $I$ expected and did not get was: 
Question 3. (Answer this if you have had a previous group or Individual counseling espertence at Lutheran Family Service,) I found ay Yellov Brick Road experience to bet (more helpful, sane, less helpful).

Question 4. (Answer thle if you have had a previous group or Individual counseling expertence elsewhere.) I found my Yellow Brtek Road experience to be: (more helpeul, same, leas helpful, )

Question 7. The counseling aethods used (Transactionil Analysts and Cestale Therapy) were: (very helpful, somewhat help(ux, not helpful).

Question 8. My level of trust and confldence in my group leaders was: (high, average, low).*

Question 9. The usefulness and/or application of my Yellon Brtelt Roed expertence to any "real IIfe sttuations" st home and woric are: (very useful, somewhat useful, not useful), wh

wouestion 8 was changed on the questlomnalres used in the second year (1974) of data collection to have two parta: aa. My Level of trust and conftdence in my Change group leaders was: $\mathrm{bb}$. My level of trust and confsdence In my ectelvity group leaders was:.

whestions 9 and 10 relate only tangently to cllent satisfaction but were Included as an attenpt to measure change and "carry-over" of change outstde of Yellow Brtck Road. 
Question 10. Changes in me have been mentioned by others: (often, sonetirnes, not at ali).tw ActIvLty group validity was addressed by: Question 5. BeLng involved in a tine re-structuring activity was! (helpful, no effect, harmEul).

Question 6. The effect my activity group had on hat I accomplished in change group was: (great effect, scine effect, no effect).

Internal progran conststency was to be measured by comparing responses within Routes, between Routes whthin Bloelss, and between Blocks,

The reader w111 note that there are elght questions relating to client satisfaction and only two relating to activity group valldity. This is because ellent sutisfaction was vlewed as a very broad area having many different aspects whteh requitred escanination. Whereas, activity group validLty was seen as a wuch more focused area.

The process of data ratrieval was begun by stratifyIng the client's questionnatres Elrst by blocks, and secondly by routes within blocks. There were five Blocks in the Erst program year. Blociss 1 and 2 had two routes each, Blocis 3 had three routes, and Blocks 4 and 5 had four boutes. Whithin this process it was discovered that there was no data on the 
29 clients who were in Bloci, 3. (The questionnalres had inadvertenty not been admindstered that block.) So, In Lact, we had the following responses:

TABLE 1

DATA RETRESVAL, 1973

\begin{tabular}{|c|c|c|c|}
\hline $\begin{array}{l}\text { BLOCK \& ROUT2 } \\
\text { NUMESB } \\
\end{array}$ & & $\begin{array}{l}\text { OF QUESTIONAARE: } \\
\text { RECBTYSD }\end{array}$ & NO. OE CLIENTS \\
\hline $\begin{array}{l}\text { Block 1, Route } 1 \\
\text { Block 1, Route } 2\end{array}$ & & gruestionnal res & $\left\{\begin{array}{l}\text { total } \\
\text { clients }-18\end{array}\right.$ \\
\hline $\begin{array}{l}\text { Block 2, Route } 1 \\
\text { Block 2, Route } 2\end{array}$ & 4 & $" n$ & $\left\{\begin{array}{l}\text { total } \\
\text { cllents }-17\end{array}\right.$ \\
\hline Block 3 & & No Data & $\left\{\begin{array}{l}\text { total } \\
\text { cllents }-29\end{array}\right.$ \\
\hline $\begin{array}{l}\text { Blocik 4, Route } 1 \\
\text { Block 4, Route } 2 \\
\text { Blocik 4, Route } 3 \\
\text { Block 4, Route } 4\end{array}$ & $\begin{array}{r}5 \\
9 \\
4 \\
8 \\
27\end{array}$ & $\begin{array}{c}\text { questlomnalres } \\
\text { " } \\
\text { " }\end{array}$ & $\left\{\begin{array}{l}\text { total } \\
\text { clients }-38\end{array}\right.$ \\
\hline $\begin{array}{l}\text { BLocik 5, Route } 1 \\
\text { Block 5, Route } 2 \\
\text { Blocik 5; Route } 3 \\
\text { Block 5, Route } 4\end{array}$ & $\begin{array}{r}8 \\
9 \\
4 \\
\frac{6}{27}\end{array}$ & $\begin{array}{l}" 1 \\
" 1 \\
n\end{array}$ & $\left\{\begin{array}{l}\text { total } \\
\text { clients - } 38\end{array}\right.$ \\
\hline TORAL: & 67 & & TOTAL: $\quad 140$ \\
\hline
\end{tabular}


The second program year, 1974, also had 5 Dlocks. Each Blocic had 4 routes, The following data was collected:

\section{TABLE II}

DATA RETRIENAL 1974

BLOCK \& ROUTE NO, OF QUESTIONNAIRES NO. OF CLIENTS NUNGBSR RECEIVED

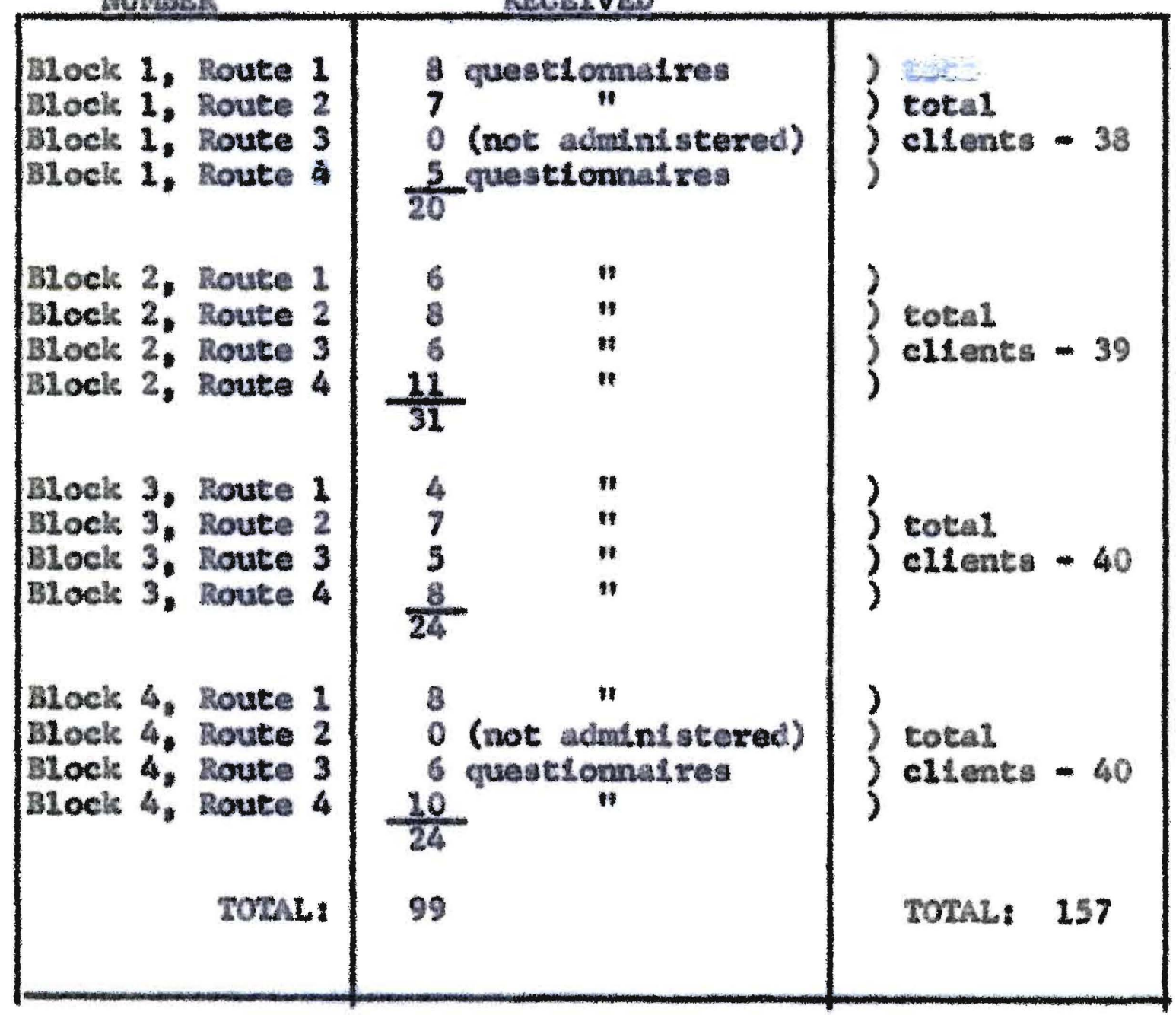

(Block 5 data was collected later and is not included in this study. The results did not vary from the other Blocis.) 
The discrepancy between total ellents and conpleted questlonnatres is explatned by a high drop-out rate Block 1 , absenteefsm from the last sesston when questionnatres are adininistered, and fallure on the part of the group leaders whose responsibllity it was to admindster guestlonalres. Followmup wth clients who dropped out Indieated that the reason for this was two-fold: 1) elients having differtng expectations of the progran (mostly that it would be "all fun") than what we were In fact offering: and 2) our Inabi1Ley to offer expected chlld care services in the first two blocks.

After duviding the data by blocks and routes, we conputed the otatstical date, mean, range and standard deviation (See Appendin $\mathrm{a}_{\text {.) }}$ for each of the ten numerical itens on the questionalres whth each route. The data was then arranged on a table which allowed us to look at the progregalon of responses from Block 1 through Block 5 of 1973, and Block 1 through Block 5 of 1974, comparing means and atandard devlations. A further step was to complie a second table of data from the routes of Blocic 5 of 1973, coaparing means and the standard deviation between the routes whlch allowed a look at the internal consistency of responses whthin a program slock. We further looked at the relationship between questions. For exasple, question 1, "My expectations 
of Yallow Brick Road were met." and question 13, "I would surasurtize ary Yellow Brlelk Road experience as."

Finully, Regresston Analysis was used to deternatne wether or not there was a statsticaliy signiflcant difference among blocks in the responses to the questions. All ten questlons were used to predlet the block. TheoretLcally, 1. persons in any one block were responding in a different manner froa the other blociss, this difference could be 1dentrated. 


\section{RESULTS}

The results are presented on Tables 3 and 4 . The Tables are set up by question (horizontally) and by progran Block (vertlcally). The Tables present a Block-by-Block comparison of each question by mean. They show an overall progression In responses fron Block 1, 1973, to Block 1, 1974. The means generally becone higher showlng a more favorable response to the program.

Block 2, 1974, means are overal1 lower than those of the preceding Block 1, 1974. There is, agein, an overall progression in means from Blocic 2, 1974, to Block 4, 1974, wlth the means generally beconing higher. This suggests an Increased Eavorable response to the program, although the high means of Block 1, 1974, are not agaln reached. Block 5, 1974, means are generally lower than those for any other Block of that year.

A probable explanation for the drop In means of Block 2, 1974, fs that at the end of Block 1, 1974, (the Mock wth the hlghest means) flve of the most skilled and experienced group leaders were made P1lots (tralners) leaving Guides with less experience and ski11 to lead the groups.

Durdug Block 5, 1974, (the last Block of the year) Guldes were generally "burned out" and progran morsle was 10w, probably accounting for the low means of that Block. 
Regardless of the drops in means in Block 2 and Block 5, 1974, total mons* for 1974, are overall higher than total means for 1973, agaln showing a favorable progression.

Total two year means are relatively high, ranging from 6.10 on question 10 to 8.50 on question 7, generally demonstrating that cllents felt Eavorable toward thelr Yellow Bricli Road experience.

Also presented on Table 4 is the followmup data of a 50 percent randon sample of the populatton of Block 4, 1974. Although the means of the follow-up data are not statstelcalIy algntficantly different from the other mean scores, they are generally lower. ThLs suggests that the data may be inEluenced by the "high splrits" of the Travelers on the last night of the progran when the questlonnatres are administered.

*Standard deviations were also computed on this data but are not presented. Generally the standard deviations becone progressively lower throughout the two program years denonstrating greater consistency in reaponses. 


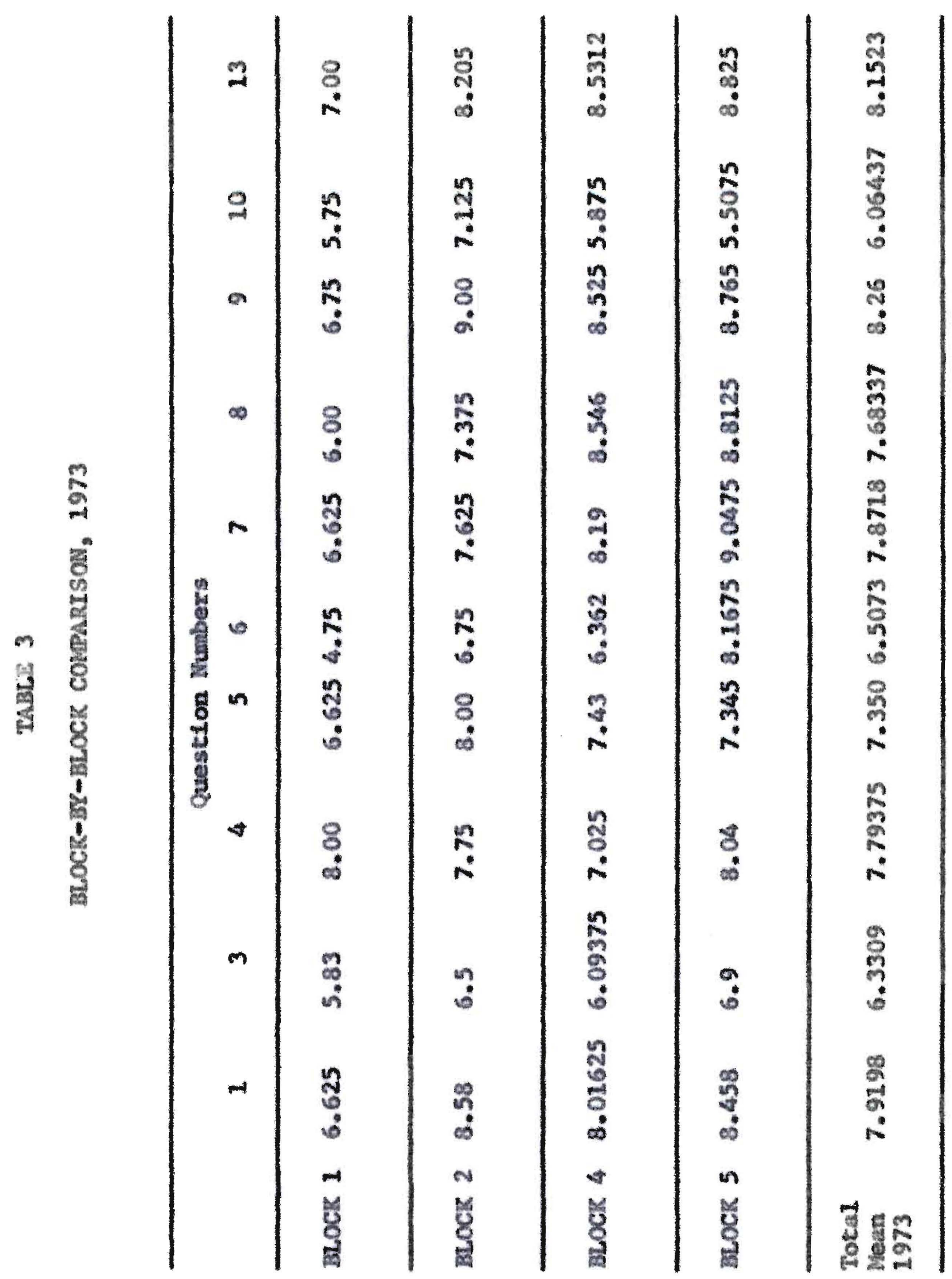




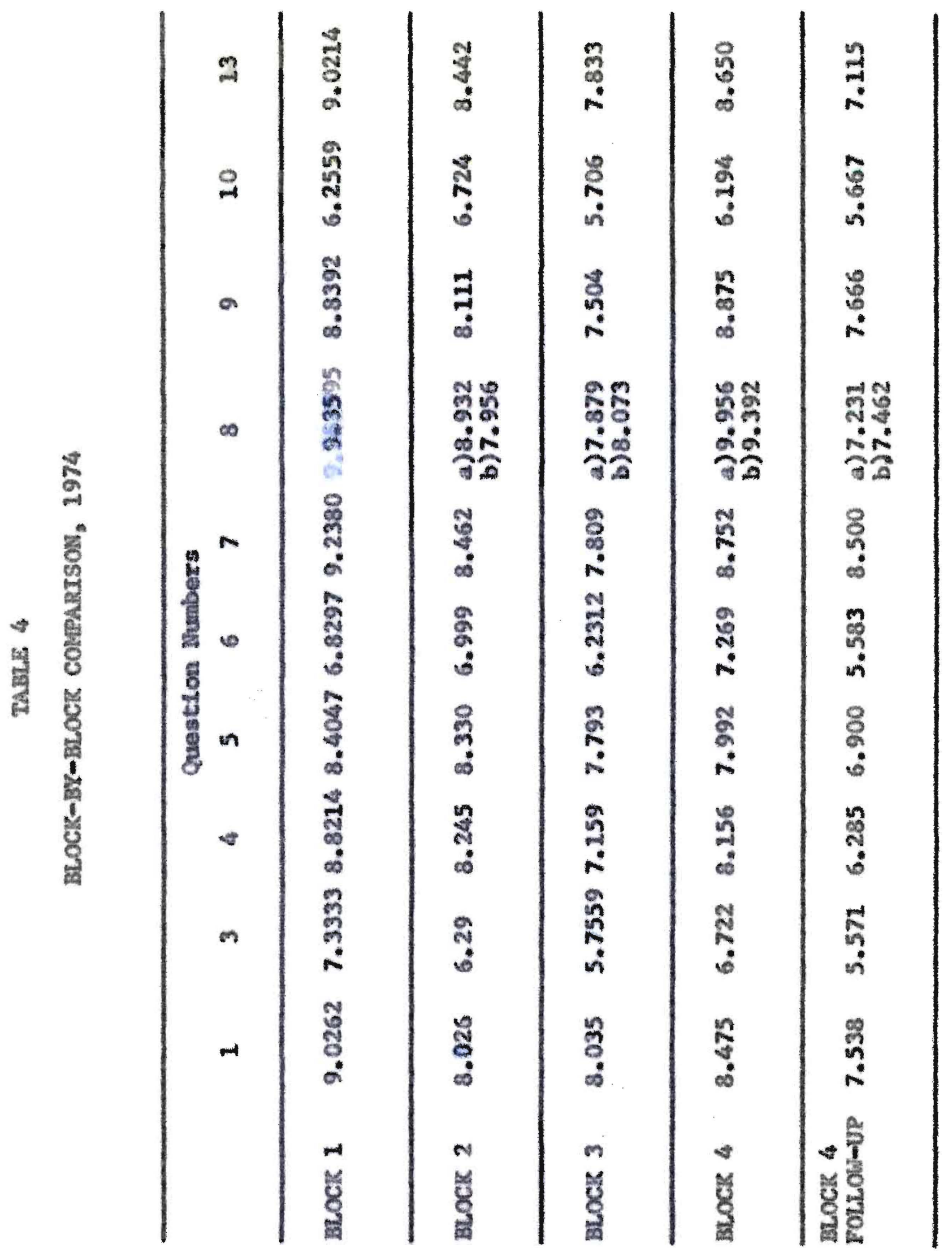


An additional measure of Internal prograa conslstency Is shown In Table 5. Data collected about Block S, 1973, contains a Route-to-Route compartson whin that Block, RLndLng no slgntflcant statistical inter-lioute correlation or difference, (See Appendis D. Intra-Block Consistency*) When a regresston analysis was run on this data, it catablished that:

1. There are no signiftcant dLferences Inter-Block: ratinga glven Yellow Brick Road for one Block of Its functioning are generally sinllar to ratings for any other Block. This holds true for the followmp questlonnafre admint stered four months later to Traverers Eron Blocie 4. 1974.

2. There are no algntifleant relatLonshtps between answers for any of the eleven or twelve questions on the evaluation (qquestion 8 was expanded to $8 \mathrm{a}$ and $8 \mathrm{~b}$ ). These IIndings maike a strong statenent about Yellow Brtek Road's consistency, while miniming the significance of varlations that surfaced bhlle simply conparing one mean to another, Overall consistency and subele d1fferences in the responses to each question w11 be discussed below, wh Interpretations offered for both. 
INTERPRETATION AND CONCLUSIONS

Interpretettion of Results

The interpretation of resules w111 be presented by questlon. (See Queatlonnalre, Appendsx C.) Followlng each questlon the extrewes of responses are glven In parentheses: e.g., (favorably to unfavorably). These responses relate to the nunertcal seale of 10 through 0 ( 10 betng favorable and 0 being unfavorable) used for rating each guestlon. The two year wean as found on Table 4 (See Results Section) is also presented. For exarmple, Question 1. "My expectations of Yellow Brick Road were met," (favorably to unfavorably). Two year mean, 8,04. Thus, $8.04 \mathrm{ks}$ the overall response on a 10 to 0 scale for that question. The response can be seen as Eavorable rather than unfavorable.

1. My expectations of Yellow Briek Road were met: (Eavorably to unfavorably). Two year mean: 8.04

Although expectations were met nore favorably as Yellow Brtek Road developed, the Increase is not statistically sigalfleant. This may be due to the Individuality of client expectations; L.e., if a Block 1 Traveler expected the exeltement and disorder of a new venture, the Traveter's expectakfons were 11kely to be met.

The grestion does not ask about quality but only whether 
or not results parallel expectattons. It was hypothesized that responses to Question 1 anght correlate whth those to Question 13, "I would sunmarize ryy Yellow BrLel Road oxperzence as: (very helprul, somewhat helpful, no help)," allowing the Interpretation that clients measure Yellow Bricli Road's value by how closely it meets their expectations. There is no. algnteleant relatlonship; in fact, wean responses to Questlon 1 are generally Lower than to Question 13.

3. (Answer this gruestion If you have had a prevtous group or Individual counselsng expertence at lutheran Fantly Service.) I found my Yellow Brick Road experience to be: (nore helpful to less helpfitu). Two yeaz mean 6.29

Yellow Brick Road differs Erom Lutheren Fandly Service counseling expertences in two major ways: 1) the four-hour: format ineluding the edme-restructuring activity group is untqgue to Yellow BrLek Road, 2) Yellow Briek Road groups are Led by paraprofesstond 1 volunteers; Lutheran Fandly Service counseltng groups are led by professtonal soctal workers. It is difftcult to know whether Travelers' Eavorable response was to the different format or to the paraprofesstonal group leaders or both or just a "vote of confidence" for Yellow Brlek Road, Another varlable whlch may have Lnfluenced reo sponse to this question is that sone Travelers expertenced Individual, one-to-one, counseling at Lutheran Fanily Service 
and group Coumseling in Yellow Brick Road. So their reaponse maly be comparing Individwal to grous treatnent modelitles. 4. (Answer this queation if you have had a previous group or Lndividunl counseling expentence elsevhere.) I found wy YoLLov Brtelc Road experienee to be: (nore holpLit to Less helpful). Two year mean: 7.73

It was expected that response to this question comparIng Yellow Brtek Road wh th all other counseling experlences would be highes than response to the previous guestion which compared Yellou antelk Roud to Lutheran Famly Servlce. The Zavorable response may in pare be a response to the group cormseling style which eraploys Transactional Analyss and Gestalt Therapy techniques, the combination of which is not generally used in this geographic area outside of Lutheran Fanily Service.

5. Belng involved in a theerestrueturing activity was: (helptul to harmful). Two yeas meass 7.74

6. The eftect my activity grous hed on what I aceons pld shed in change groug was: (great effect to no effect). Two year mean: 6.62

One of the goals of Yellow BrLels Rosd and this zesearch Ls testing the concept thet tmomestructuring activities support therapy and help malntaln its beneflts. The program's sophistication in dealing with therrestrueturing activities 
hes Incressed whth elearer understeanding of activity theory, greater exphasis in tralning, Increased destgn and leadership sict1s, heightened In-yrogram status, Yet, the ratings from one Block to the next show no atgnifleant increase. There are two posstblo explanations. Although overall program expertise Increased, Guldes often use activity groups for their Intelal expertence in leading, a place to "try their whgs" " Thus, skil1 galns are balanced by neweoners" gauchertes, and the end produet remalns constant. Beeause of Lts novelty, Travelers sey not realize what an activity group's Inpact has been; 2. 6., not recogni,zed that anxlety expertenced during a given exerelse in activity group led into work durting change group.

7. The counseling wethods used (Transactonal Analysis and Gestalt Therapy) were: (very helpful to not helpful). Two year mean: 8.22

Responses to this question may indicate that Travelers felt good about the counseling methods used, however, this may also reflect group leaders' alc111 level. As shown on Tables 3 and 4, there is a marked rise in means from Block 1, 1973, 6.62 to Bloclc 1, 1974, 9.23. This may be a direct result of the training that the original Guldes recelved. Responses Eron Block 2, 1974, through Block 5, 1974, renain high but show no progressLon. By this polnt in the prograr, 
Guides at wdely varying ski11 levels were leading groups.

8. a.My level of trust and confidence in my activity group leaders was! (high to 10u). Two year mean: 8.35 b. My level of trust and confldence in my change group leaders was: (hlgh to 10w). Two year mean: 3.86 Unt12 Block 2, 1974, Travelers" reactions to thetr leaders were comblned in Question 8. Since then, the question has been divided. Thls allows for more differentlation, although averaglng still occurs: reactions to elght activity leaders (two for each of 4 Routes whin a Block) are included in the Blocik mean for 8a. This process supplles data about Travelers' feelings for all the leaders withln thefr Block (usually ten Travelers uth two activity group leaders and two Change group leaders, multiplied by four Routes per Block). It bluxs, however, reactions of these ten people to their spectfle Leaders. These scores range from 10. (Block 4, 1974, Route 3) to 6.94 (Block 3, 1974, Route 4), "* yet show no stgnifleant difforenees inter-block. Overall, there 1s conststency in Travelers' Levels of trust and confldence. There are elso varlatlons worth noting and these have been used for Gutde Seedback.

Question 9. The usefulness and/or application of my Yellow Brtelk Road expertence to any "real IIfe sftuatlons" *Indivldisal Route means are not shown on Tables 3 and 4. 
at hone and work are: (very useful to not usefiul). Two year mean: 3.30

Perhaps more than any other single question, the high response to this question demonstrates the suceess of the Yellow Brtek Road program. As discussed in the program rationale section, Yellow Brlelk Road was created to assist people in developing new, posttive Life styles. In other words, to pronote some "carry-over" of therapy experilences to "real 21fe sttuations." Response to this question Indicates that Travelers were successful in attalning that carryover. It vas hypothesized that there would be a signtficant ralationship between response to this question and Question 13. "I would sumaartze my Yellow Bxtek Road experience as: (very helpfirl, somewhat helpful, no help). Although statsteally there is no significant relationshlp, a look at Individual Block responses seem to indieate that a relationshlp may extst but is not statlstleally measurable. For estample:

Question 9 Question 13

Blocle 4, $1974 \quad 8.8758 .650$

Block 5, $1974 \quad 3.356 \quad 8.208$

10. Changes in me have beon menttoned by otherst (often to not at all). Two year mean: 6.11

Thls is the lowest two year mean and is consistently 
the lowest mean of all the questions. Thls was the one guestion whtch attergted to get at sorne objective measure of change. Probably the question doos not suceed in dolng that. 13. I would summarlze ay Yellow Brick Road experLence as: (very helpful to no help). Two year mean: 8.30 ThLs tas an important question in two regards. Information sought was: 1) Generally, how was Yellow BrLek Road accepted by those it served? 2) What aspects of Yellow Brlek Road led Travelers to evaluate It as they did? (It was thought that this data would whow relationships between the means of this question and varlous other questions. There were no slgnifleant reldtlonships.). Response to Question 13 has been increastngly postelve, ranglag froca Block 1 , 1973, mean of 7. to the "high polnt" zesponse of 9.021 a year Later, Block 1, 1974. Reasons for the response-which varlables natter most-are not weh elearer now than they were before collecting and processing two years of data, stnce no statisteally sigatfeant relationships or differences were uneovered. Thls may be a coment on the level of signiflcance used, .05, rather than on this research or on the answerablit ty of the question. Although no answer provides Information and consistency is certalnly a valuablo IInding, the posstbilty of developing research tools to deal more exactingly with questions and hypotheses ralsed hore 
seens worthwhile,

The lower mean scores of the followm data also suggests that the timing, as to when the questionnatres are adminlstered, is ingortant. And, that continued followmp studies may give importane information as to the personal value of his/her Yellow Brlcik Road expertence as viewed in retrospect by a Traveler.

\section{Conelustons}

Overall, the Information gained from the questionnalres 1s that:

2. cllent satisfaction is hgh, a two year mean of 8.30 (as shown on Table 4 as a response to Question 13) on a scale of 0 to 10.

2. Internal prograa consistency extsts: there is no statisteally sLgnefleant dLfference for any of the vartables measured, etther Inter-3lock or (In the sample checleed) Intra-Block,

3. Activity group valldity remalns an unlonown, since no significant relationshlp can be shown between responses to ectulty groups and other responses. The trend, hovever, Is Eavorable; activity groups were generally seen as helpê. 
UTILIZATION

Because the researchers are Yellow Brick Road's Director and Tratner, opportunttles to use the dats have been rlch. The data has been utilized in three ways?

2. For declston-nalding wtehin the progran,

2. For Leedbacis to Gutdes.

3. For Inforntng our sponsor, Lutheran Faxtly Service, of partletpants' reactions to the program.

At the begtnntng, the Director and Tratner read each set of responses eagerly, hoptng the scores would be high, enjoying the written connents. (A Eavorite was, "I wanted to work on not putting things off-but I dectded to worik on that later,")

Reading was for reassurance, as well as for Information, wth the assunption that high ratings Implied satisfled Travelerseewhich in turn reflected on the quality of the progrorn, This concept altered, however, because ratings were generally conststent, while subjectvely sone Blocks seemed to go well, others comparatively badly.

Thts varlanee, which outsLde zesearchers mght have alssed, has influenced Its leaders thinktng about Yallow Brick Road and affected 1ts functioning. Since Travelers zate sLmLlarly the "good" Blocics and the "bad" ones, perhaps they are reacting to more vartables than our questionnalre 
measured. Enthuslasn of volunteers involved in thelr own growth sometimes seens contaglous, and that splrit-more than skillsmeray influence Travelers. If this is so, then what standards should be used to declde tho 1 s ready to lead groups? Or do these results merely demonstrate agaln the diffleulty of measuring how clients fudge counsellng? Such guestions have brosdened the concept of what Yellow BrLlek Road is and does and have provided distance helptul in dealIng with program 1ssues other than evaluation.

Feedback to Guldes has occurred at periodic meetings, Overall data and tentative interpretations have been presented, wth Guldes showing Interest not only in the data, but also in sharing their own hypotheses. Charts have been posted showing group leaders how thelr Change or Activity groups were rated. Guldes could read not only the ratings gtven his/her group, but other groups offered during the same Block,

Differences that "average out" when questionnalres fron elght groups are combined (Block mean), can be seen clearly on such a chart. (Block 3, 1974.) In two areas the charts seened more effective than previous verbal statements had been:

Sone Guides, who apparently thought positive connents from PLLots were support rather than evaluation, became more 
confldent after seeing statistes which confirwed that they had been well recelved by thetr clients.

The concept that activity grous content should coordinate with change group functioning moved from befng an oplnion to a generally accepted "verity," as Gutdes looked at responses to Question 6. (The effect my activity group had on what I accomplished in change group was:)

Benefits from this use of data probably would have been greater if a presentation and chart had been offered at the end of each stx-week Block.

Sharing of this data with Lutheran Family Service stafe has been both formal and Informal. Agency interest in volunteers, activity groups and like expertences, is high so special attention was pald to findings in these areas. Charted deta (Tables 1 and part of 2) was presented in an al1-staff meeting following Block 3, 1974, and active brainstorming about the meaning of the findings followed.

One of the posstble future uses of this material is to report our flndings in one of the progressional journals. Although Transattional Analysis theory states that tinerestructuring 18 an inportant aepect of therapy, few uses of that concept have been reported and, to our lknowledge, there are no research Elndings. 
EPILOGU:

One of the ongolng values of this research has been in focusing attention on progran Issues that might have been overLooked In the busymess of Yellov BrLek Road's day-tooday funetloning. The research supports bellef in client satisfaction and internal program consistency. The third ma jor question-me valldity of activity groups and whether they contribute to change-remalns unanswered: there is too 11.tie correlation to say it does, and too much subjective data to say 2t doesn't.

The questionnalre, deslgned at the beginalng of Yellow BrLck Road, reflects the Director's and Trainer's coumitment to activity groups: two qquestlons out of thirteen. At the beglnning, activity group leaders were offered less training than ehange group leaders. Now 50 percent of Yellow Brick Road Sunday al ght tralning focuses on activity group leaders. Activity tralning lags behtnd change group training in other areas (minthons, marathons): itls still ellmbing up from Its Inltial second blling.

The bellef that activity groups are valuable perslsts, along with the realization that thls hypothesis hasn't been proven here.

AdditLonal impresstons, not measured by the questionnatre but stgntficant to seetng Yellow Brtek Road whole, are 
as follows:

Partleipation in Yellow BrLek Road seened to enhance career develognent of Gutdes and PLlots. A number of people were offered jobs on the basts of sle1lls learned at Yellow BrLcis Road, In faet, the "commaty" aspects of Yellow Brick Road served as a network for Ifnding jobs, apartments, babysteters, etc., thus generally contributelng to the gquality of participants' 11ves. This supportive quallty also may have proved Importent to merabers of the Yellow Brick Road corwstrnley leavtag spouses, as about one-fourth did. One explanation for this is that by offertng a supportive conmunity. Yellow Bxtck Road attracted people whose needs were not belng met in their home sttuation. Yellow Brick Road then became a eatalyst for their disstisfaction by offering what Guldes often reported experlenelng as nore attention and affection than they were accustoned to, leading to dectslons to divorce. Yellow BrLek Road seems to have offered Incentive and support for 11fe changes regarding education. Alnost a third of the Guldes and Plots have entered graduate prograns durIng the two years of Yellow Brtels Road's extstence. Again, It can be assumed that the program attracts people looking for self- and slet11-Lagrovenent. Even so, the supportiveness of the Yellow BrLick Road conwuntty and the successes galned in woriclng with Travelers seens to play a part in 
people defining thenselves as potentlal mastar's degree holders in soctal work, education and counseling.

Yellow Brtck Road was destgned to meet cllents' needs, but It soon became apparent that $1 \mathrm{t}$ net Guides' needs even more potently. Of the Initial twenty Guldes who had made a one-year conmstment to the program, seventeen stayed for the second year. Thts has been a mtxed blessing. On the one hand, It could be seen as a clear statenent of satisfactLon, that what YeLLow Brick load offered, Guldes wanted. On the other hasd, it created problems, partlcularly because the origtnal design hadn't considered this possibility. Sometimes it seens that alleglance to Yellow Brick Rosd has been at the expense of other activities. In the criterla used for selecting Gutdes (Appendis A.), bonus polnts were awarded for "potential impact in present employ" ment setting," WhLle some have used experiences froa Yellow Brtek Road to enhance theis work Iffe and there is commulty pride about this, others withdrew from settings where they might have made a difference since their Yellow Brtek RoadInfluenced standards for openness, attention and impactfulness were not belng met. Thts Ldealization of Yellow BrLck Road and their destre for it to meet more and more of thelr needs then led to demands that thelr soctal Interests and polltscal asplrations be met through Yellow Brlek Road. 
Orlglnal exphasls on tralning sometimes lost its centrality, Whether good or bad in thenselves, the Impact of such demands has put extra stress on a design which didn't antlelpate then. In general tt can be satd that Yellow Brick Roed's popularIty has crested umexpected problens, and progran revistons are belng considered to deal with them.

One such problem is the growing body of people whth counseling sk111s but no certiflcation. Proposed solutions vary from using Lutheran Fandly Service as an unbrella under whlch they ean work as pald counselors to IImfting the time-and hence the tratninge-a Guide nay have In Yellow Brick Road. WIth the current miss of newconers and Culdes whth several years' expertence, tratning has become increasingly difficuit. The time-1imited proposal suggests viewing the destze to remain In Yellow Brick Road past a given tine-mone year or elghteen months-as a problem, not a success: that Yellow Briclc Road has becone assurrogate for other 11fe experiences rather than an enhancement of thern.

One solution to this dilerma might be to provide less speclallzed skill training to avold tralnees needing Yellow Brtek Road as a setting to use their sicills, slnce they can't be used in the general commanty wthout further accredita tion. If the training were more general, wth greater emphas1s on commulcation and group process, it might be more 
generally transferable to present work settings and thus wealeen Gutdes' dependency on Yellow Brtek Road providing a client population with which to work.

Another Issue ratsed by Guides' destre to rexaln in Yellow Brlek Rosd concerns thelr own growth, whether the Yellow Brlek Road coraminty Inadvertently supports selfInvolvenent, Intellectulization and therapy as a IIfe style. Because social Interaction is based on the Guldes' Interest in his/her ow therapy and in worlking with cllents, conversattons often seen stuck on the reporting of self-expertence level. This is a stage cllente in therapy generally go through, but it seens that Involvement in Yellow BrLek Road prolongs the stage, w.th consequences as yet unknown.

These social transactions may have an even more detrimental effect, when Gutdes becone so focused on provlding support and counseling for one another that appropriate professlonal help isn't sought, Yellow Brick Road Guldes sometines hesitate to get outside help, based on fantasies that 1) beeause they lead groups they shouldn't need coumseling thenselves and 2) what other tralnees provide is sufflclent. Paradoxically, the warnth that is usually constdered a genulne asset of Yellow Brick Road can be used to avold the reallzation that an Individual needs help beyond Yellow Brtek Road's resources, Although the Director, 
Tralner and nost of the PLlots make statements to the contrary, such bellefs seem to persist.

There is an "Ingrown" gqualtcy to Yellow Brtek Road, and such bellefs exemplify 1t. Perspective and consultation that might have helped avold such conseguences wes not provided, wh the Chalrman of Lutheran Fandly Service malking only two on-sight visats to the program.

While this conmunfeated trust and confldence, it offered no checic agalnst the Director's and Trainer's enthusLasm and nearsightedness, It seems fair to conclude that Yellow Brick Road's count tment to serving Travelters was met whthout such back-up, but that cutderrelated problens could have been eased with more outslde observation and guidanee.

Ironleally, the populartty of Yellow BrLek, Road has created unforeseen difflculties, how these new challenges are met wi11 determine Yellow BrLek Road's ultinate success. 
APPEMDIX A

GUIDE SELECTION

Crtterta for Tratnees

Tralnees are selected on the basis of the following crtterta:

1. Famillartty wh thansectional Analyst.s

Applicants are rated on a 0 to 10 scale based on their fannliartey of concepts and terninology and thelr ability to apply both.

\section{Awareness}

Applicants are rated on a 0 to 10 scale based upon their awareness of self and others. This pertalns to 1ittle professor (Intultion) awareness as well as Adult.

3. Conpleted successful therapy or equivalent

Applicants are rated on a 0 to 10 scale based on thelr personal emotional health and thel $x$ fandilartity wth therapy techniqques. This also Implites the absence of a "don't change" in junetion or havling suceessfully worked it through.

4. Tralnability

ApplLcants are rated in IIve subecategortes, wh th each worth a posslble two points.
a) wi11 14sten and learn
b) 24ked by tralnex and director 
e) Like trainer and disrector

d) corant tment and motivation

e) cooperation (w1.12 attend regularly and are not: opposed to the focus of the program and the religtous posttion of the agency)

5. Spectal Sik11s

Applicants may recelve up to ten polnts based upon spectal sict11s they possess and expdrtences they have had which will benefft the program and give then a head start toward belag activity or change guides (yoga, art, therapy. etc.)

Bonus points are awarded (two each) to applicants on the followtng criterita:
a) reside in Southeast Portland
b) male
c) are employed by Portland Action Conalttees Together
d) have potential impact in present employment setting
e) are over 40 


\section{APPENDIX A.}

Oxiginal Cuide Selection

1. Fand14artty with Transactional Analysis

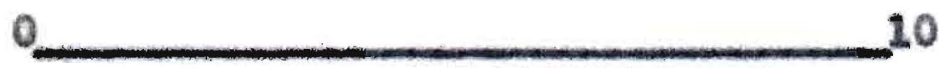

2. Awareness

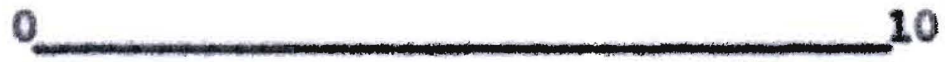

3. Completed successful therapy or equivalent

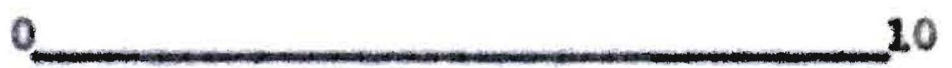

4. Trainabi1sty

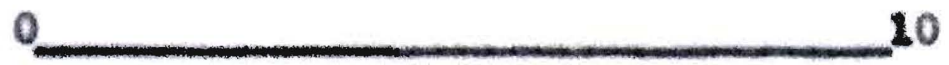

5. Spectal SkL11s

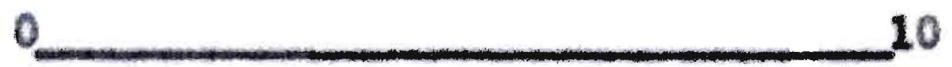

NOTES:

Total polnts 
Gutde Apolleante" Bvaluation

TOURIST APRLYNG TO BECOME GUTDE

Date.

Block

Activity Group Leader. (Ctrele own narae please)

Actlvity Group Observer.

Change Grous Leader.

Change Grous Observer

I see this person becoming a Guide at this time yes__ no

List three characteristics of this tourist:

What Is your overall "hte" about this person becoming a gulde: $\begin{array}{lllll}1 & 2 & 3 & 4 & 5 \\ \text { No way } & & & & \text { Fuliy confldent }\end{array}$

Degree to which you personally like the person:

$\begin{array}{lllll}1 & 2 & 3 & 4 & 5 \\ \text { Not at all } & & & \text { Very much }\end{array}$

To what degree would her/his script Interfere whth "heartng" and expertencing Yellow BrLek Road? $\begin{array}{ccccl}1 & 2 & 3 & 4 & 5 \\ \text { Seldion } & & & & \text { Continuous } 2 y\end{array}$ 
As a gulde, her/hts major strength(s) would be:

As a gulde, her/his jor conslict(s) and/or blind spot(s) would be:

"And another thing I want to oay 1s..." 


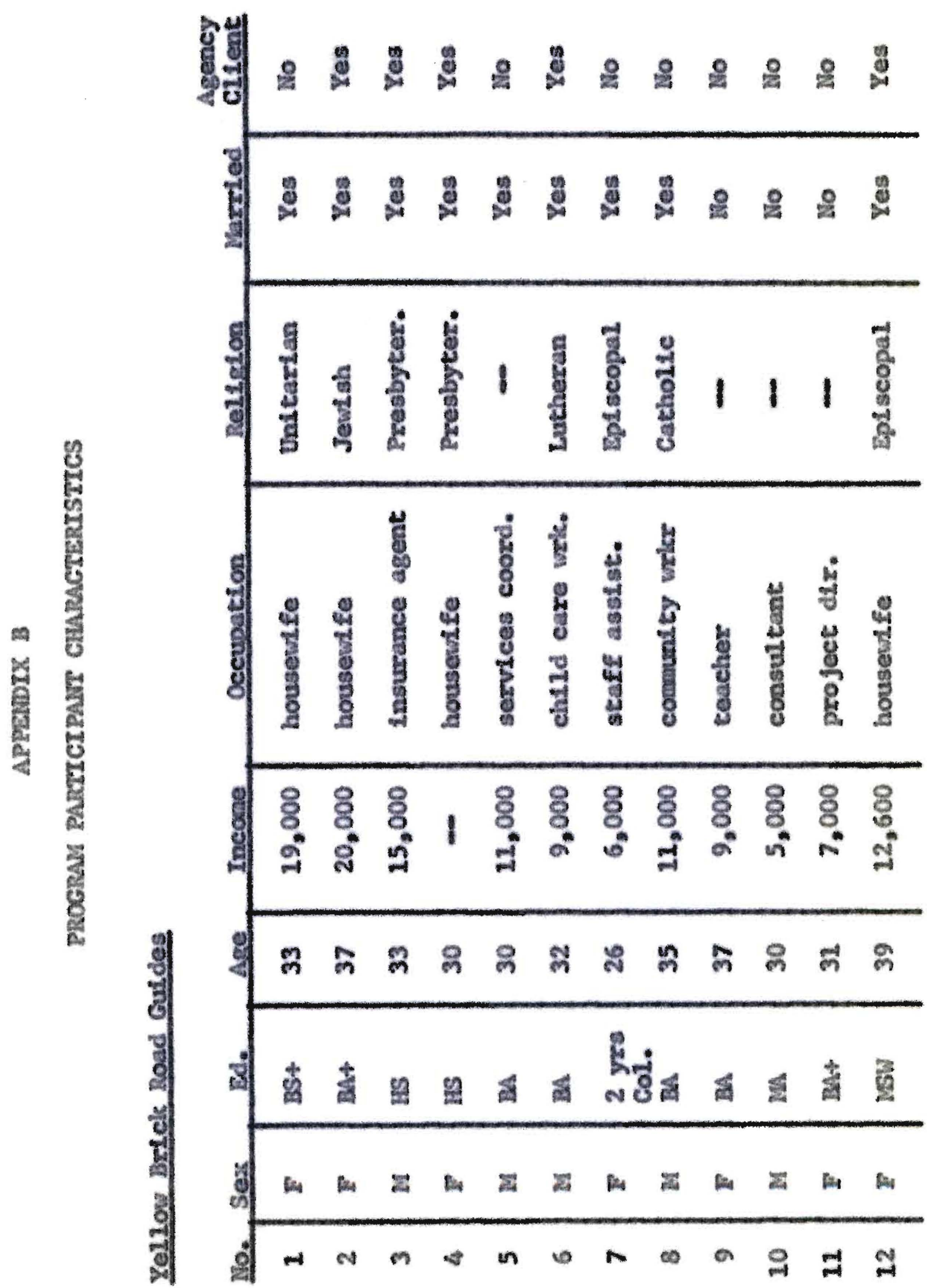




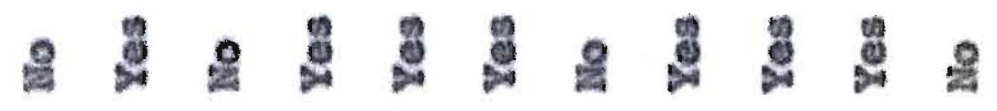

2

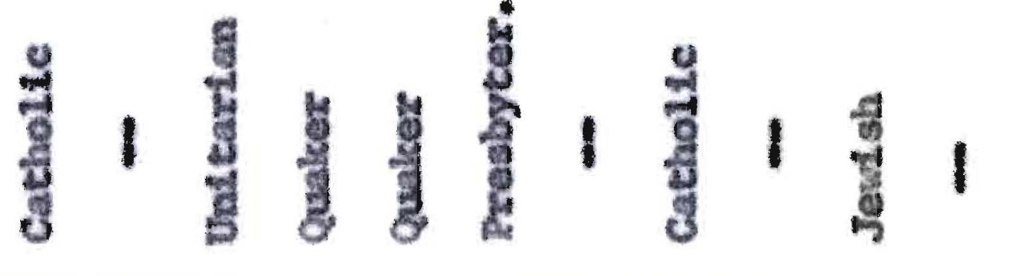


8

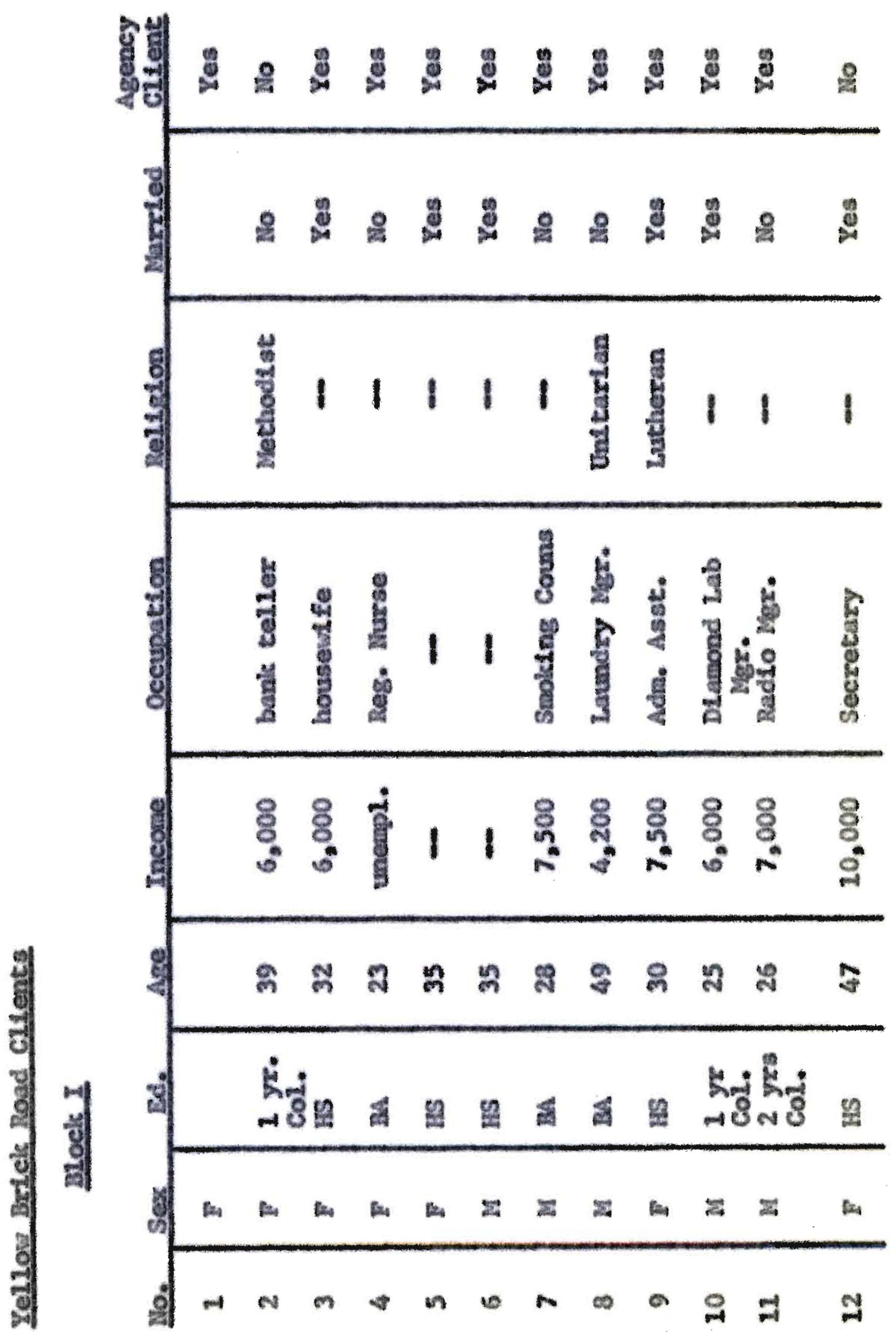


9

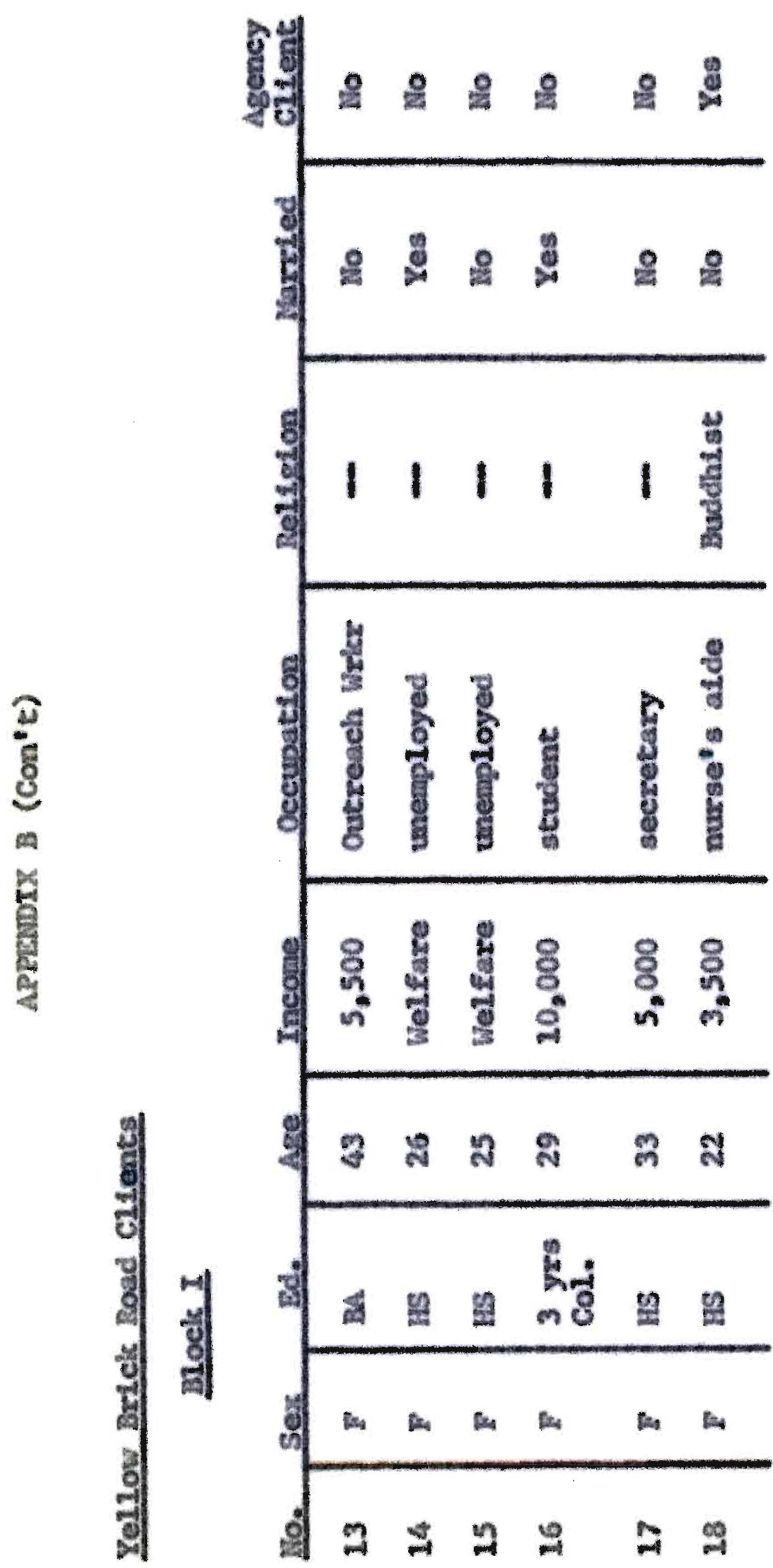


8

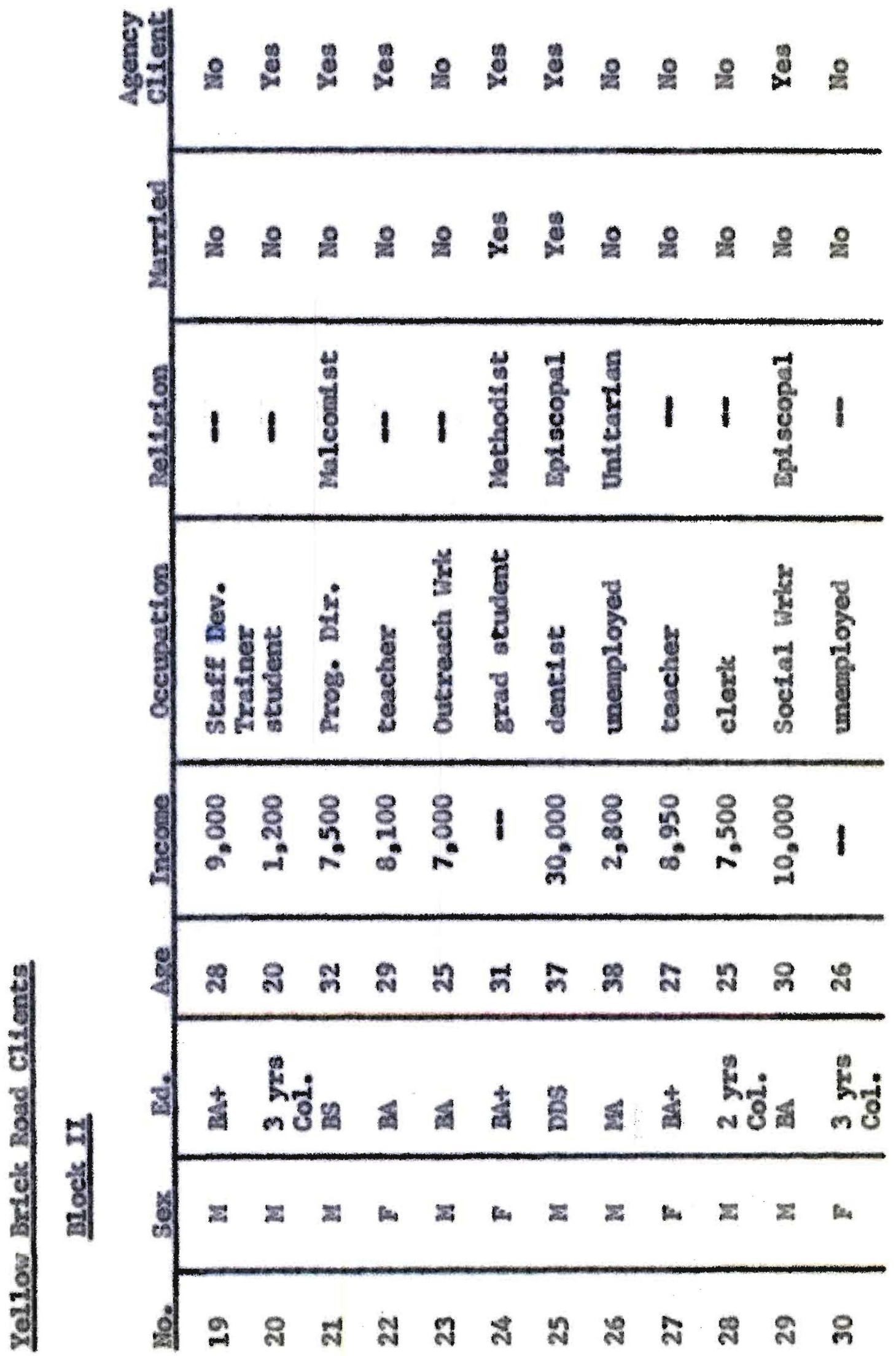


ำ

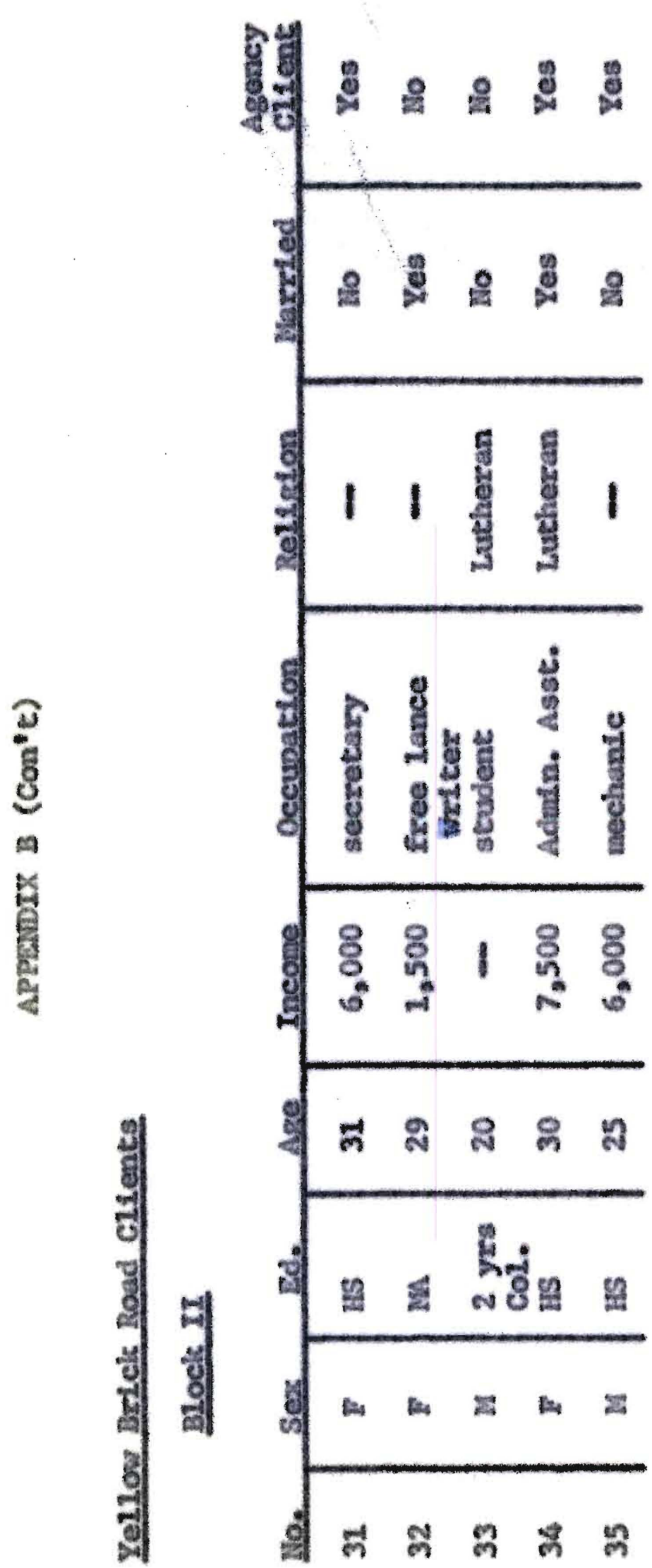


in

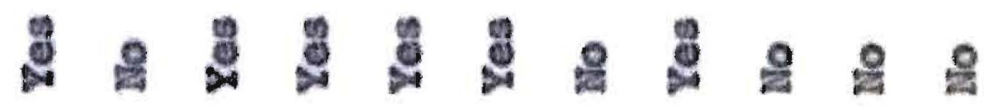

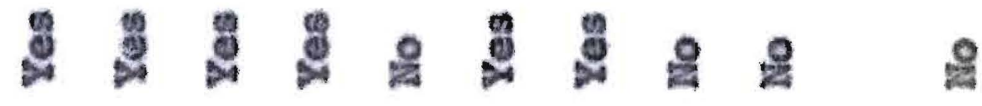

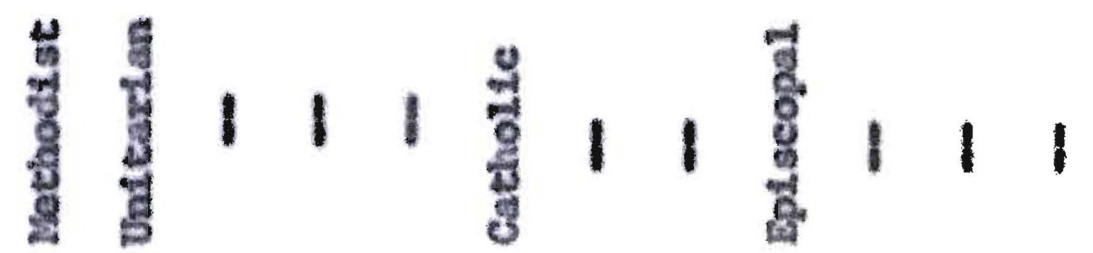

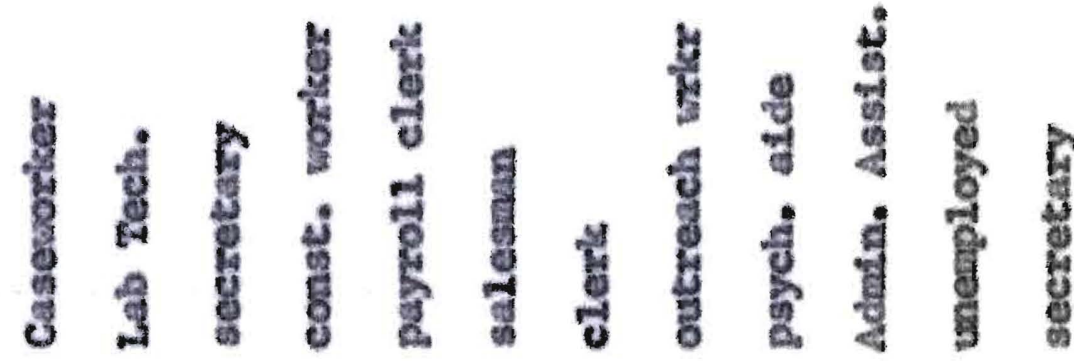
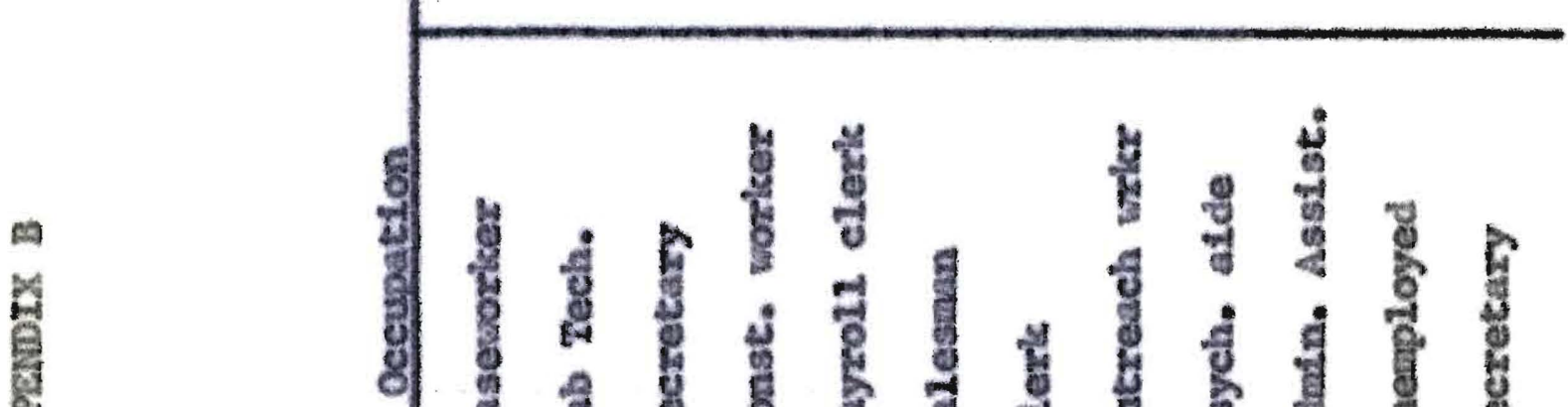

$$
\text { a. }
$$

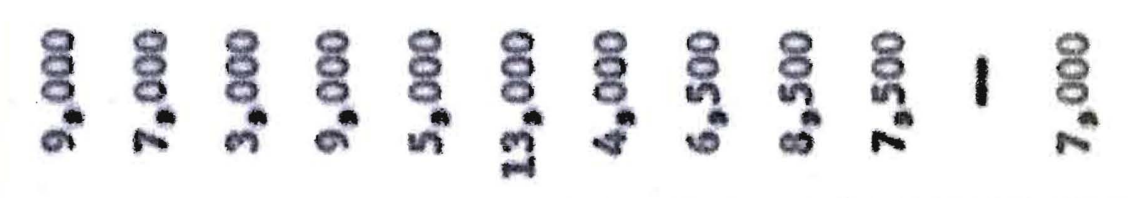

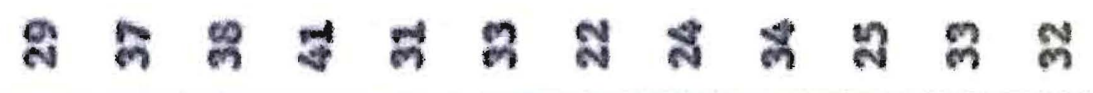

해 행

-

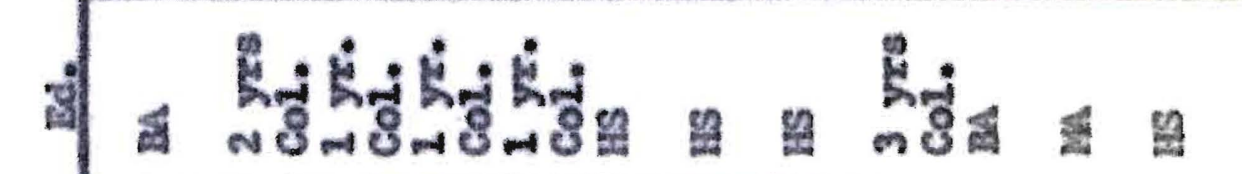

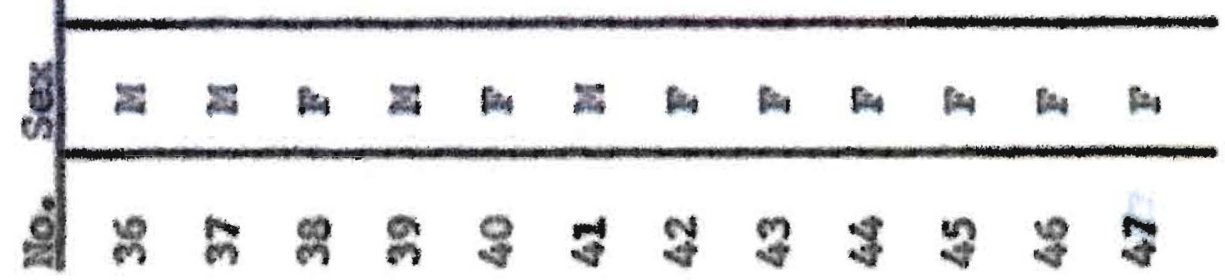


in

迹

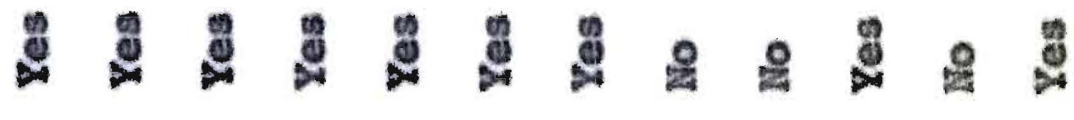

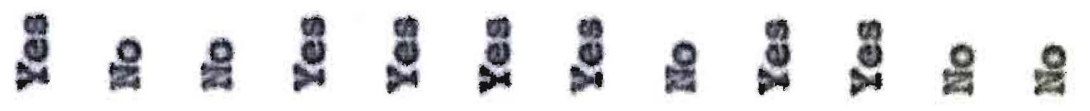

형 कै कै

है

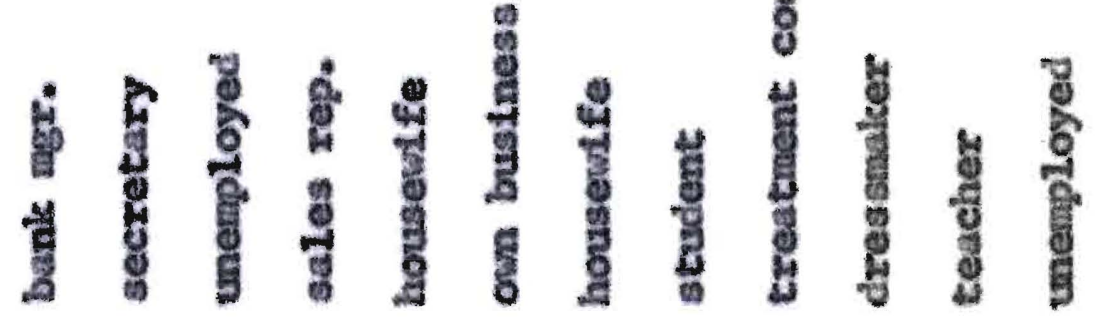

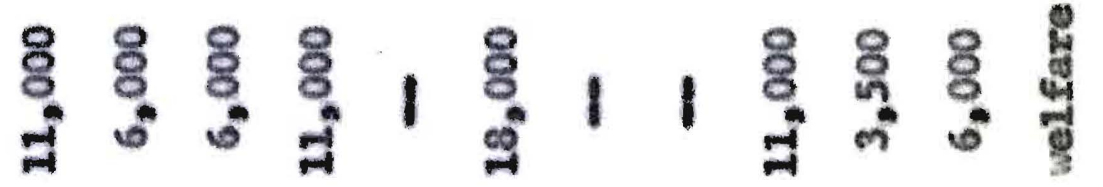

ก

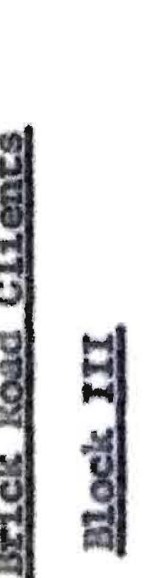

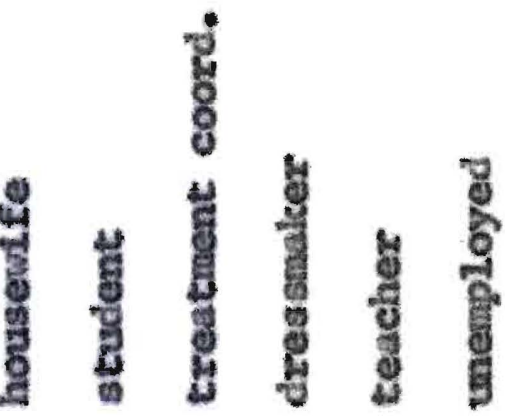

\begin{tabular}{|c|c|c|c|c|c|c|c|c|c|c|c|}
\hline 绕 & 朊 & 욜 & 包 & 3 & 때 & & $\frac{1}{4}$ & 재 & t) & $\mathcal{2}$ & 1 \\
\hline 2 & is & 124 & 浔 & (u) & $\mathbf{z}$ & and & m & 표 & in & 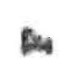 & 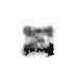 \\
\hline
\end{tabular}


กำ

3
8
8
3
4
4

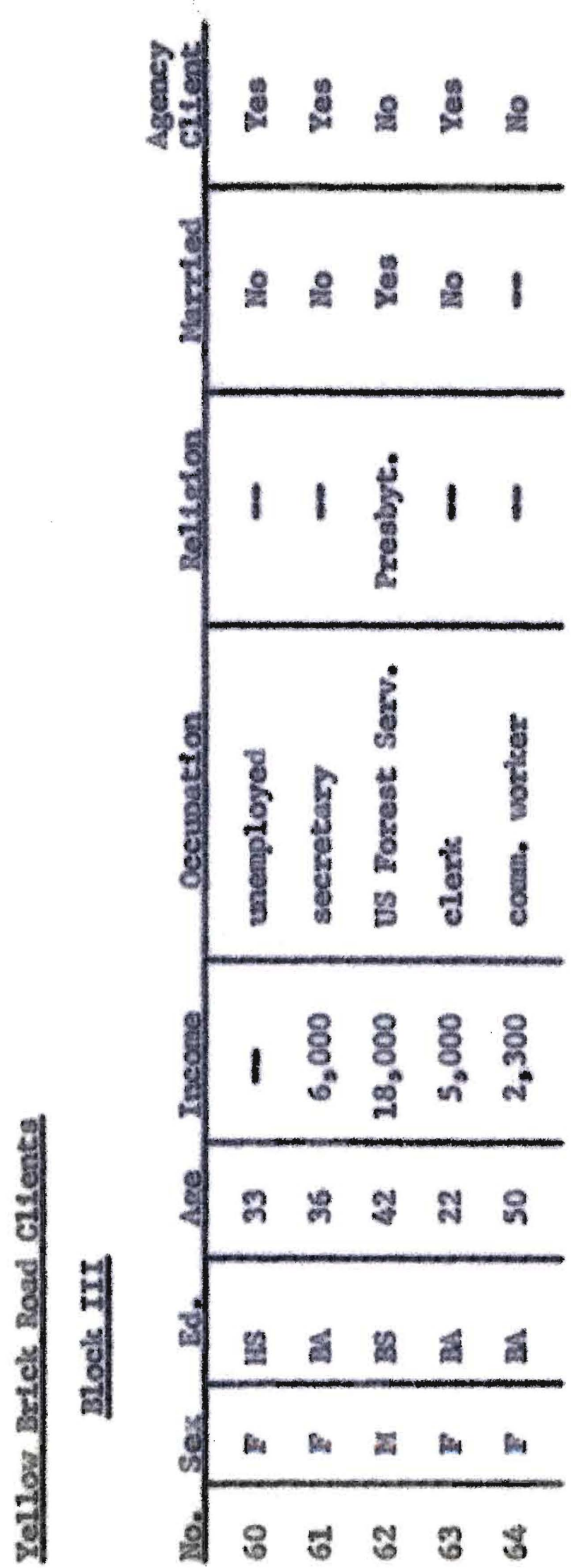


APTENDTX C

QUESTONATRE

Yellos Brelcis Road Evaluatelon

SEX:

How many previous bloclcs of Yellow Brtelk Road have you attended?

Group Leaders:

Change:

Activity:.

1. My expectations of Yellov Briels Road were met (ctrele one:

Eavorably

10

98

$7 \quad 65$

4

$3 \underset{2}{\text { unfavorably }}$

2. What I espected and did not get was:

3. (Answer this question 28 you have had a prevtous group or Individual counseling expertence at Lutheran Fandy Service.) I found my Yellow Brteik Road expertence to be:

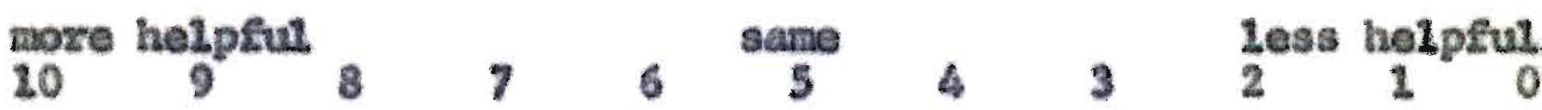
4. (Answer this gquestion if you have had a previous group or Individual counseling expextence alsewhere.) I tound my Yellow Brteic Road expertence to be: more helpful 10 holpter. 10 8

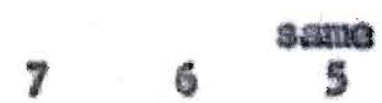
$4 \quad 3 \quad \frac{1}{2}{ }_{1}{ }_{1} \quad{ }_{0}$ 
5. Belng Involved In a tine-restrueturing settvity was:

helpêt.

109

$8 \quad 7 \quad 6 \quad{ }_{5} \quad 4$

$3 \quad 2 \quad \begin{array}{lll}\text { hazraful } \\ 3 & 1 & 0\end{array}$

6. The effect wy aettvity group had on wht I accomplished In elaange group was:

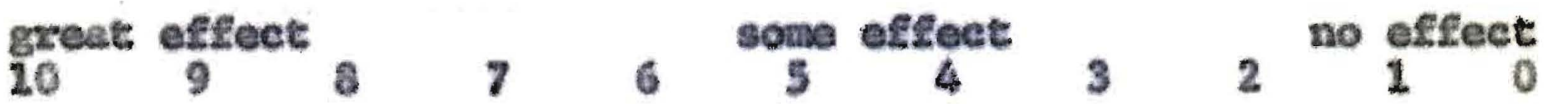

7. The counseling methods used (Transactonal Analysis and Gestale Therapy) were:

vory helpful $9^{2} \quad 7 \quad \begin{gathered}\text { somewhat helpful } \\ 5\end{gathered}$

8a. Wy Level of trust and confldence in my Activity Group

leaders was:

high

10

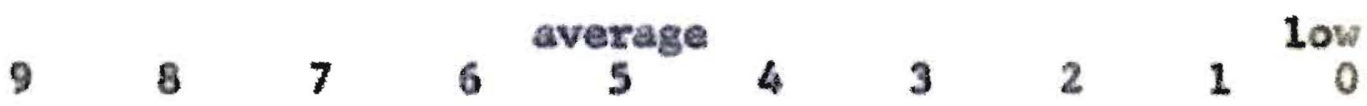

8b. My level of trust and confidence in my Change Group

leaders was :

high

10

$9 \quad 8 \quad 7 \quad 65^{\text {average }} 4$

43

2

$1 \quad 10$ w

9. The usefulness and/or application of my Yellow Brick Road experience to any "real 1ife situations" at home and work are: very useful

10

98

$7 \quad 6 \underset{5}{\text { somewhat }} 4$

$32^{\text {not }}{ }_{1}$ useful

10. Changes in me have been mentioned by others:

often

10

9
8

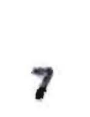

$6{ }^{\text {sometimes }} 4$

3

$$
2^{\text {not at all }} 0
$$


11. Most change has taken place (circle one):

1. In the way I feel about ayself

2. In relating to fardily

a. mate b. children $c$, brother or sister

d. parents

3. In relating to others outside fanily

4. In relating to stuations (buch as job)

12. My fee was (circle one):

1. About right

2. Higher than $\mathbf{I}$ expected

3. Lower than I expected

13. I would sunnartze my Yellow Brtck Road experlence as: very helpful 10 2 8 $7 \underset{6}{5} \underset{4}{6}$ $32 \quad \begin{array}{cc}\text { no help } \\ 1\end{array}$ COMENTS AND SUGGESTIONS: 
ก

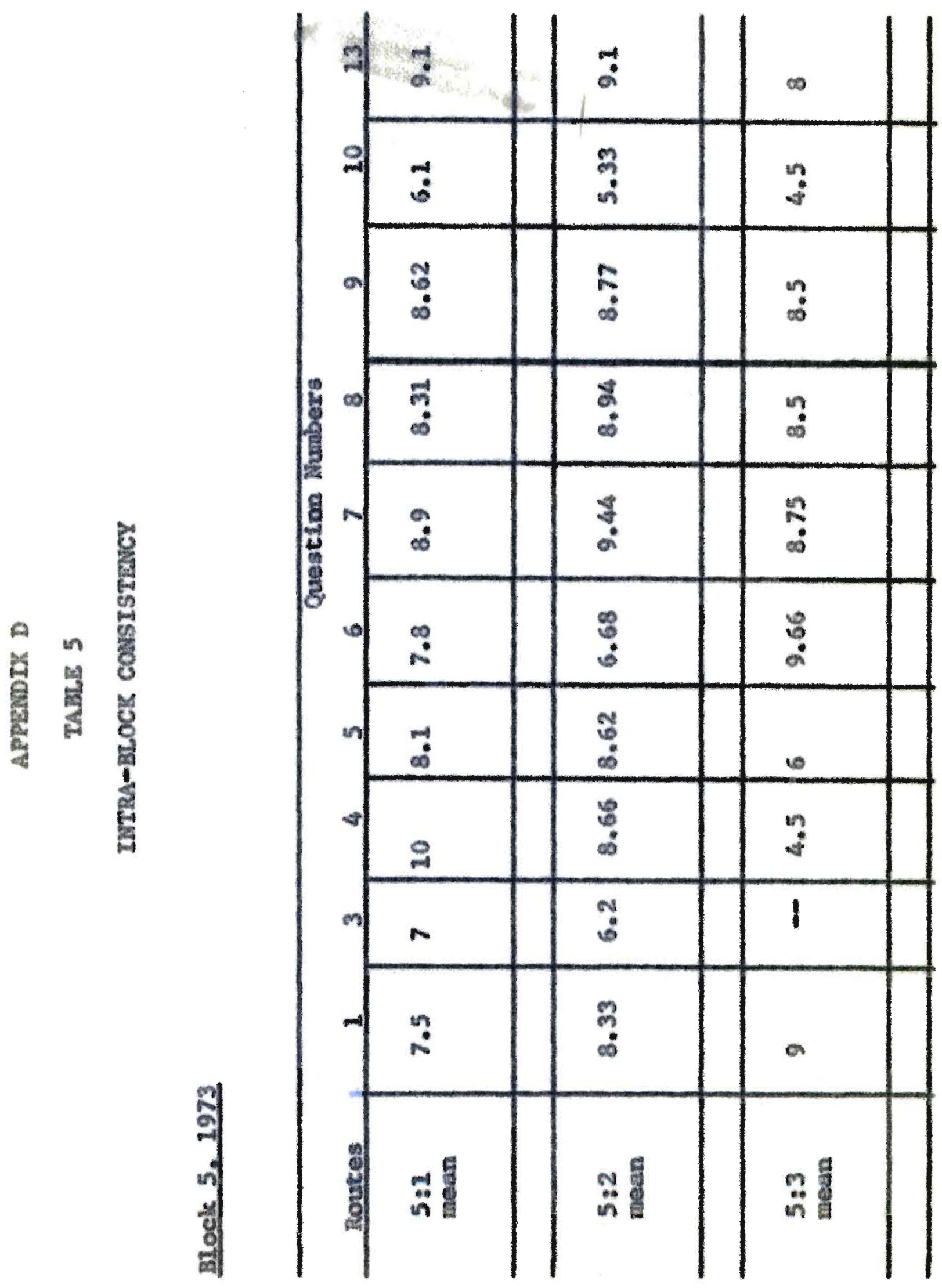


ox
un
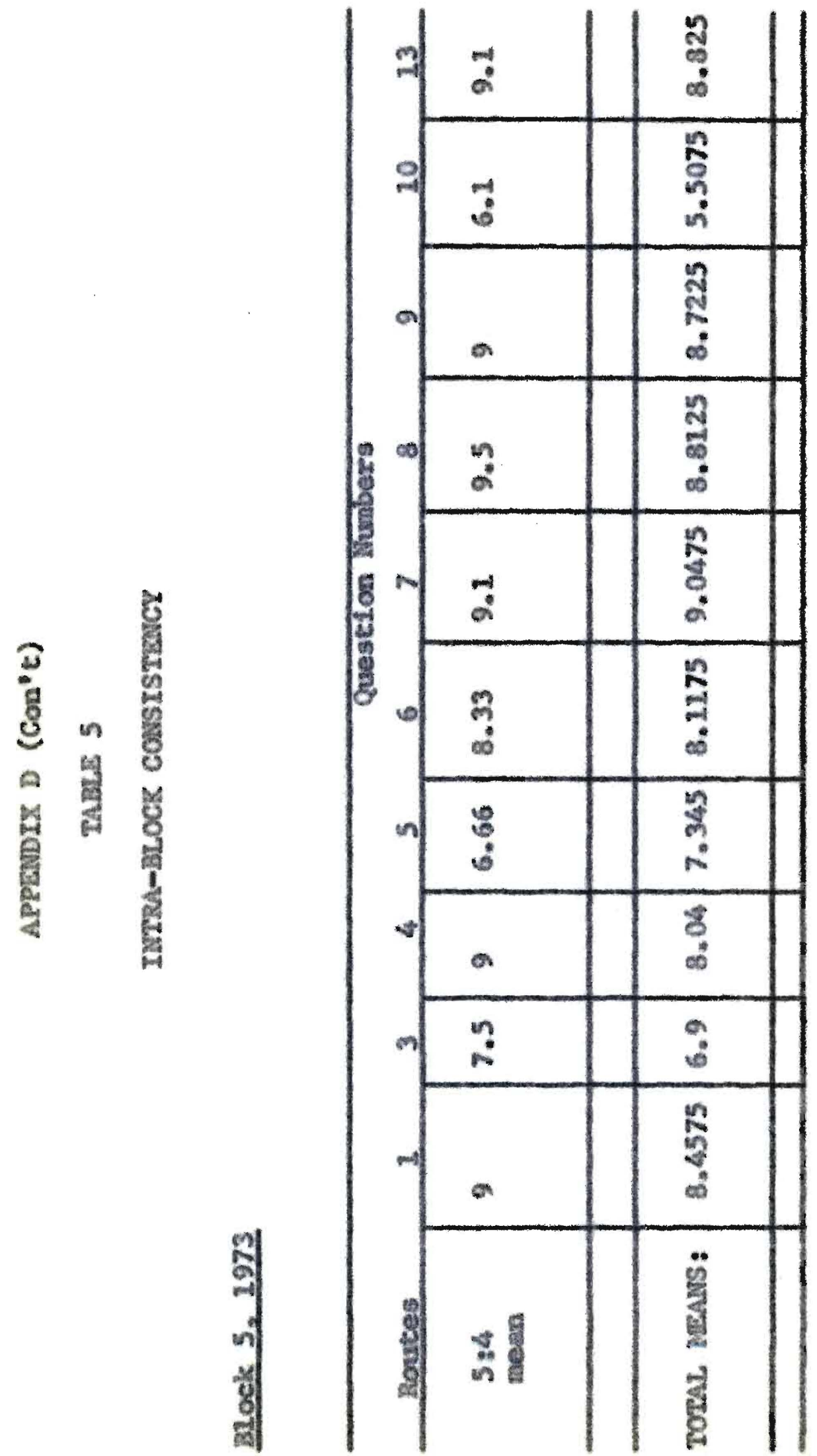